\title{
A Distinct Hibiscus sabdariffa Extract Prevents Iron Neurotoxicity, a Driver of Multiple Sclerosis Pathology
}

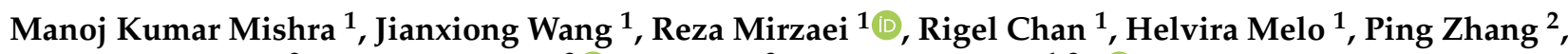 \\ Chang-Chun Ling ${ }^{2}$, Aldo Bruccoleri ${ }^{3}{ }^{(\mathbb{D}}$, Lin Tang ${ }^{3}$ and V. Wee Yong ${ }^{1,3, *(\mathbb{B}}$
}

1 Hotchkiss Brain Institute, Department of Clinical Neurosciences, University of Calgary, Calgary, AB T2N 4N1, Canada; mkmishra@ucalgary.ca (M.K.M.); jiwang@ucalgary.ca (J.W.); reza.mirzaei@ucalgary.ca (R.M.); rigel.chan2@ucalgary.ca (R.C.); francisca.cavalcante@ucalgary.ca (H.M.)

2 Department of Chemistry, University of Calgary, Calgary, AB T2N 4N1, Canada; pzhang05@gmail.com (P.Z.); ccling@ucalgary.ca (C.-C.L.)

3 AnthoBio, Calgary, AB T2N 4N1, Canada; aldo.bruccoleri1@ucalgary.ca (A.B.); linaileentang@gmail.com (L.T.)

* Correspondence: vyong@ucalgary.ca; Tel.: +1-403-220-3544

\section{check for}

Citation: Mishra, M.K.; Wang, J.;

Mirzaei, R.; Chan, R.; Melo, $\mathrm{H}$.

Zhang, P.; Ling, C.-C.; Bruccoleri, A.; Tang, L.; Yong, V.W. A Distinct Hibiscus sabdariffa Extract Prevents Iron Neurotoxicity, a Driver of Multiple Sclerosis Pathology. Cells 2022, 11, 440. https://doi.org/ $10.3390 /$ cells 11030440

Academic Editors: Hans Zempel,

Natja Haag and Juliane Bremer

Received: 17 December 2021

Accepted: 25 January 2022

Published: 27 January 2022

Publisher's Note: MDPI stays neutral with regard to jurisdictional claims in published maps and institutional affiliations.

Copyright: (C) 2022 by the authors. Licensee MDPI, Basel, Switzerland. This article is an open access article distributed under the terms and conditions of the Creative Commons Attribution (CC BY) license (https:// creativecommons.org/licenses/by/ $4.0 /)$

\begin{abstract}
Iron deposition in the brain begins early in multiple sclerosis (MS) and continues unabated. Ferrous iron is toxic to neurons, yet the therapies used in MS do not counter iron neurotoxicity. Extracts of Hibiscus sabdariffa (HS) are used in many cultures for medicinal purposes. We collected a distinct HS extract and found that it abolished the killing of neurons by iron in culture; medications used in MS were ineffective when similarly tested. Neuroprotection by HS was not due to iron chelation or anthocyanin content. In free radical scavenging assays, HS was equipotent to alpha lipoic acid, an anti-oxidant being tested in MS. However, alpha lipoic acid was only modestly protective against iron-mediated killing. Moreover, a subfraction of HS without radical scavenging activity negated iron toxicity, whereas a commercial hibiscus preparation with anti-oxidant activity could not. The idea that HS might have altered properties within neurons to confer neuroprotection is supported by its amelioration of toxicity caused by other toxins: beta-amyloid, rotenone and staurosporine. Finally, in a mouse model of MS, HS reduced disability scores and ameliorated the loss of axons in the spinal cord. HS holds therapeutic potential to counter iron neurotoxicity, an unmet need that drives the progression of disability in MS.
\end{abstract}

Keywords: experimental autoimmune encephalomyelitis; human neurons; iron; multiple sclerosis; neurodegeneration; neuroprotection; oxidative stress

\section{Introduction}

Multiple sclerosis (MS) is a disorder of the central nervous system (CNS) characterized by the loss of myelin and oligodendrocytes and of neurons and their axons. Symptoms include fatigue, tremor, stiffness, painful spasms, diplopia, poor balance and cognitive impairments, and these vary from one patient to the next depending on where lesions occur in the CNS [1]. In most patients, MS begins with discrete episodes of neurological dysfunction (relapses) followed by remission; this is relapsing-remitting MS [2]. Within 10-15 years in many individuals, there is disability progression often independent of relapse(s), and this is referred to as secondary progressive MS. In a minority (10-15\%) of patients, disability progression is unrelenting from the outset, referred to as primary progressive MS. Before the formal diagnosis of MS, a first demyelinating episode suggestive of future MS is termed clinically isolated syndrome. Radiologically isolated syndrome refers to asymptomatic individuals who have undergone a brain magnetic resonance imaging (MRI) scan for various reasons, and where an MRI lesion with similarity to those characterized in MS is observed. Emphasizing the need to treat MS early, brain atrophy is already observed in radiologically isolated syndrome [3], where $\sim 50 \%$ of subjects are destined to be diagnosed with MS within 10 years [4]. 
While the initiating cause of MS is unknown, immune cells are activated in the periphery and in the CNS; several peripheral blood leukocyte populations enter the CNS to produce neural degeneration [5,6]. In addition to mediators of injury produced by immune cells, such as cytokines, proteases and reactive oxygen species, factors released by CNS structures can also be injurious, and one of these is iron $[7,8]$.

Iron is a co-factor required for many processes in the CNS, including the formation of myelin by oligodendrocytes [7]. It is also a transition metal, changing between ferrous and ferric forms, with a strong capacity to generate oxidative stress. The reaction of ferrous iron with $\mathrm{H}_{2} \mathrm{O}_{2}$, referred to as the Fenton reaction, produces the highly reactive hydroxyl radical. Iron is thus managed safely in homeostasis by a range of mechanisms, including iron importers and exporters on the surface of cells, by transporters such as transferrin, by storage within cells in ferritin cages, and by a variety of ferroxidases [9]. Inflammatory processes alter several of the regulators of iron handling in cells and exacerbate iron accumulation [10]. If unbuffered, the extracellular ferrous iron becomes a mediator of cell injury.

The potential dangers of iron in causing neurotoxicity across several neurological diseases including MS, and in normal aging, has been reviewed [11]. Iron damages cells through several mechanisms, including the induction of ferroptosis $[12,13]$ and the generation of reactive oxygen species (ROS) [14,15]. Unbuffered iron can also cause injury by activating sphingolipid metabolism that promotes cell death [16] and by misfolding and aggregating proteins including amyloid beta, tau and alpha-synuclein [17-20]. In tissue culture, iron is lethal to human neurons [21].

Iron accumulation is documented in MS via MRI and the Turnbull histological stain in several brain regions, particularly the deep gray matter important as a conduit between the spinal cord and upper brain regions [22]. The detection of iron via MRI in the deep gray matter is found from the early stages of MS, including clinically isolated syndrome [23,24]. Iron accumulation is progressively elevated with advancing disease [25], is associated with the accrual of disability [26] and corresponds to brain areas with neuronal degeneration and demyelination [27-29]. The elevated iron in MS brains is thought to be due to be its liberation from damaged, iron-rich oligodendrocytes and myelin [7,28,29].

Despite the potential of iron to be injurious in MS, none of the disease-modifying therapies used in MS are reported to directly neutralize iron neurotoxicity. Oxidative stress caused by ROS is increasingly being targeted in MS, an example of which is the use of the anti-oxidant alpha lipoic acid [30,31], which has been shown to reduce MRIdetected annualized brain atrophy by $68 \%$ in a small Phase 2 clinical trial [32]. However, ameliorating ROS produced by iron may not overcome iron toxicity if other mechanisms noted above of iron-induced injury (e.g., misfolding of proteins) are prominent. Effective means to ameliorate iron neurotoxicity are thus required.

Hibiscus sabdarrifa (HS) is a species of the genus Hibiscus native to West Africa, but it also grows in other geographic locations. Its extracts are consumed in many cultures, where its herbal tea is known variably as sorrel, roselle, Jamaica and karkade, amongst others. It is used as a food coloring, and clinical, trial-validated results have shown it can treat hypertension [33]. It is also used for hyperlipidemia and glycemia [34].

Organic hibiscus extracts, predominantly of its calyces and enriched in anthocyanins [35], have anti-oxidant [36] and anti-inflammatory [37,38] activities in vitro. One extract protects against serum- and glucose-deprivation injury to a neuronal cell line in culture [39]; another study demonstrated the protection of another neuronal cell line against H2O2 toxicity [40]. Hibiscus extracts have been reported to reduce brain pathology and biochemical indices of oxidative stress when injected intraperitoneally into mice in models of Parkinson's disease [41,42] and Alzheimer's disease [43]. In high concentrations ( $>50 \mu \mathrm{M}$ of hibiscus delphinidin 3-sambubioside), however, anthocyanin-rich hibiscus can be toxic to cells through mitochondria-induced oxidative stress [44].

Here, we isolated an HS extract with low anthocyanin content and tested its efficacy to neutralize iron toxicity in neurons in culture and in reducing axonal degeneration in 
the EAE model of MS. We described the unexpected observations that HS potently attenuates iron neurotoxicity in culture in conditions in which strong anti-oxidants (ferulic acid) or disease-modifying therapies used in MS (dimethylfumarate, fingolimod and siponimod) could not. We also demonstrated that HS ameliorates experimental autoimmune encephalomyelitis (EAE) disease accompanied by substantial protection against the axonal degeneration of the spinal cord.

\section{Materials and Methods}

\subsection{Preparation of HS}

Aqueous extracts were obtained from dried calyxes of HS plants. The extraction was performed using a 1:8 to 1:10 $(w / w)$ ratio of dried calyxes to water, and the extracts were processed by filtration and centrifugation to remove solids. The composition of the complex aqueous extract is only partially characterized at this point, but it has low anthocyanin content compared to a commercially available capsule (see Section 3), several organic acids (e.g., glyceric acid, propionic acid, malic acid and oxalic acid) as determined using mass spectrometry and several polyphenols (e.g., gallic acid, gallocatechin and kampferol) as evaluated using liquid chromatography (data not shown). Intellectual property protection is being applied for regarding the HS compositions.

The HS liquid was dried to a powder form. Specific stock concentrations $(15 \mathrm{mg} / \mathrm{mL}$ or $150 \mathrm{mg} / \mathrm{mL}$ ) were then reconstituted in water, and working stocks were further diluted with water or tissue culture medium from the stock concentrations. The $\mathrm{pH}$ of these stock solutions was $\sim 2.9$. In some experiments, HS solution was subfractionated by passing it through a Diaion HP-20 column, and the results of HS fraction 1 are reported here. The anthocyanin level of HS solutions was measured using the total monomeric anthocyanin content assay following protocols described by others [45].

We also compared a commercial hibiscus capsule (product \# NPN 80051271) purchased from Nutritional Fundamentals for Health Inc, where the label on the bottle reads 'Hibiscus SAP, Blood pressure and cardiovascular support'. The dry powder within the capsule was constituted in water at $15 \mathrm{mg} / \mathrm{mL}$ or $150 \mathrm{mg} / \mathrm{mL}$ stock concentration.

In summary, in this study, we tested HS as an aqueous extract of the dried calyxes of Hibiscus sabdariffa plants, different HS batches to evaluate the reproducibility of extracts to protect against the iron-mediated killing of neurons, an HS fraction 1 to determine whether a particular composition of HS retains its neuroprotective activity and a commercially available Hibiscus sabdariffa capsule to investigate whether it could replicate the neuroprotective activity of our HS extracts.

\subsection{Culture of Human and Mouse Neurons, and Evaluation of Neurotoxicity}

Human fetal brain specimens were obtained from legal abortions, and their use for research following parental consent was approved by the Conjoint Health Research Ethics Board at the University of Calgary. Ethics guidelines preclude access to patient information and the cause of the abortion. Neurons of over $80 \%$ purity were obtained as previously described [46,47]. In brief, $0.75-1 \times 10^{5}$ neurons were seeded into each well of poly-Lornithine-coated, 96-well, flat-bottom black/clear plates (Falcon 353219) in $100 \mu \mathrm{L}$ of AIM $\mathrm{V}$ media (Thermo Fisher, Burlington, ON, Canada). These neurons were then used for experiments after 24 to $48 \mathrm{~h}$ of culture. Four replicate wells were used per experimental condition.

Primary mouse cortical neurons from embryonic day 15-16 pups were isolated and nurtured in Neurobasal Plus media (Thermo Fisher) with B27 Plus supplement (Thermo Fisher) as detailed [48]. Neurons were grown in poly-L-ornithine-coated, 96-well, flatbottom black/clear plates at a density of $0.75 \times 10^{5}$ neurons.

In experiments involving test reagents (e.g., HS or medications used in MS) and iron, the test reagents were applied to neurons $1 \mathrm{~h}$ before the iron. At the end of an experiment, cultures were fixed with $4 \%$ paraformaldehyde and then incubated with a Tuj1 primary antibody to label tubulin $\beta 3$ for neurons [49]. Following a secondary antibody incubation, 
labeled cells in 96-well, flat-bottom black/clear plates were imaged using the 10x/0.5 NA air or the 20x 0.45 NA air objective on the ImageXpress Micro XLS High-Content Analysis System (Molecular Devices). For each well of cells, 9 or 12 (identical within an experiment) fields of view (Figure 1A) that were in the same locations in each well of every well of an experiment were imaged for quantitative analysis. Multiwavelength cell scoring analysis in the MetaXpress High-Content Image Acquisition and Analysis Software (Molecular Devices) was used to quantify the number of neurons in these FOVs, as described previously [21], thereby providing an index of cell survival. Note that this ImageXpress method to quantify the loss of stained neurons and potential protection by test compounds was used in our previous reports where neurons were destroyed using activated microglia [50], activated T cells [51], oxidized phosphatidylcholines [49] and iron $[21,52]$.
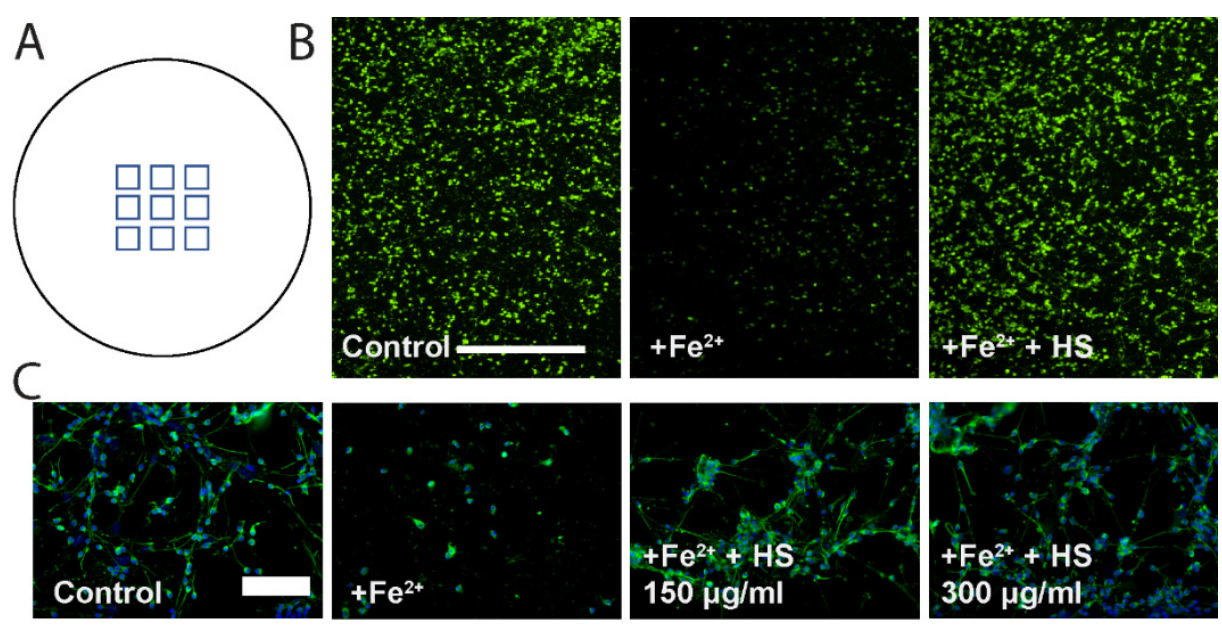

D
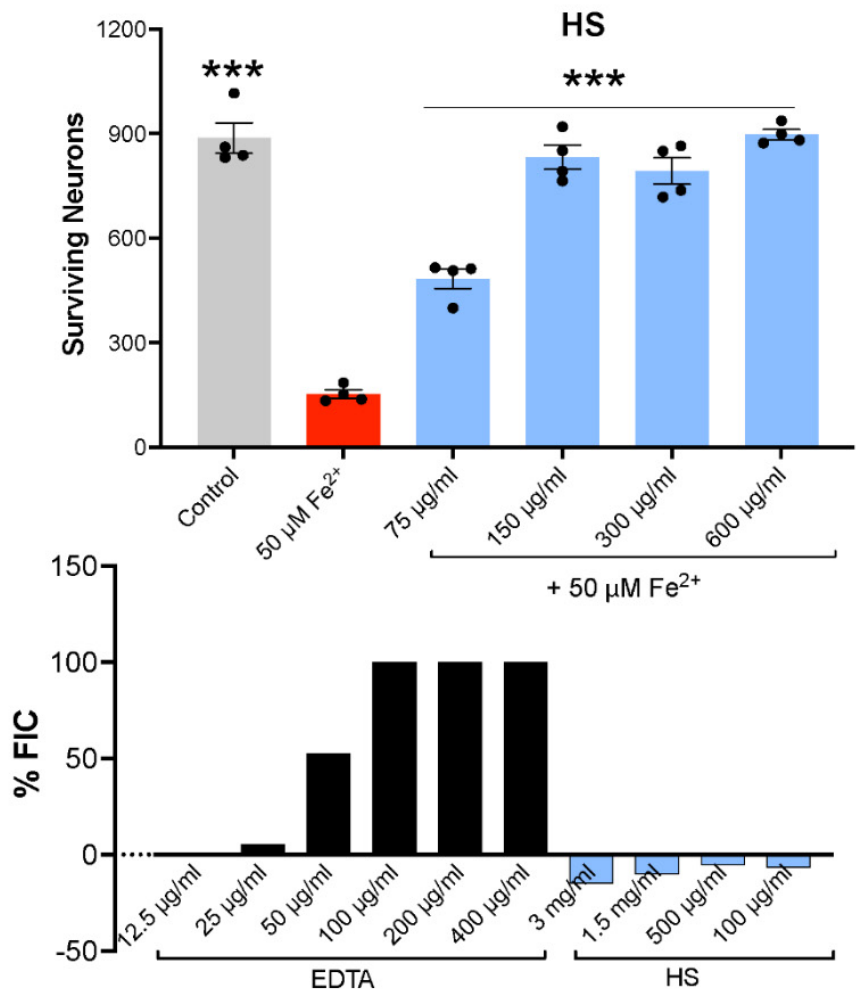

Figure 1. The killing of human neurons by ferrous iron is prevented by HS. (A) Schematic representation of the 9 (or 12 in some experiments) fields per view per well of a 96-well plate that were 
counted by the automated ImageXpress. The total count of neurons across these 9 fields is documented to represent the number of neurons that survived in that well. (B) A low-magnification image (captured using a $4 \times$ objective lens) each of a control, iron alone or iron + HS was captured well so as to visualize the substantial loss of neurons in response to iron and the protection by HS. Scale bar is $100 \mu \mathrm{m}$. (C) Tuj1 staining (green) to label tubulin $\beta 3$ of neurons shows iron $\left(\mathrm{Fe}^{2+}, 50 \mu \mathrm{M}\right)$-mediated loss of human neurons over $24 \mathrm{~h}$, which is prevented by the presence of HS. Blue: DAPI to label nuclei. The scale bar in the control group is identical across all 4 panels and represents $100 \mu \mathrm{m}$. (D) In this experiment, the killing of human neurons by $\mathrm{Fe}^{2+}$ is reduced partially by $75 \mu \mathrm{g} / \mathrm{mL} \mathrm{HS}$ and completely by higher HS concentrations. Values are mean \pm SEM, with each dot representing a well. The protection by HS of iron neurotoxicity is reproduced in two other human preparations. *** $p<0.001$ compared to iron (1-way ANOVA with Dunnett multiple comparisons). (E) The $y$-axis shows ferrous iron-chelating (FIC) ability. While EDTA chelates iron (upward direction of histogram) effectively, HS does not, even at very high concentration of $3 \mathrm{mg} / \mathrm{mL}$. We do not know the reason for the negative values, but it appears that high concentrations of HS interfered with the assay. The lack of chelation of iron by HS is replicated in another experiment.

It is important to note that there was variation across different batches of cultures, but that all test conditions were controlled within an experiment. These variations across batches of cells prepared at different times were contributed to by the initial health of the isolated cells (some preparations were healthier than others despite the desire to be as consistent as possible), different individuals isolating the cells in the first place, the density of the cell suspension for plating, the susceptibility of neurons to iron-mediated killing that can vary across preparations for reasons that are unclear, and whether 9 or 12 fields of view were quantitated in ImageXpress. Such variability across batches is reflected in the number of control neurons that differed across experiments (see, for example, the $y$-axis numbers in Figures 1 and 2). However, each experiment was internally controlled to have the same conditions of assessment. Moreover, the trend of each key result was evaluated over 3 different batches of neuronal cultures in separate experiments.

\subsection{Life Imaging of Neurons}

We sought to visualize the progressive injury to neurons exposed to iron in real time. Mouse neurons in a 96-well plate were incubated with $5 \mu \mathrm{M}$ of Cell Tracker ${ }^{\mathrm{TM}}$ Red CMTPX Dye (Thermo Fisher, catalog number C34552), which crosses the plasma membrane of all cells, and with $5 \mu \mathrm{M}$ of SYTOX ${ }^{\mathrm{TM}}$ Green Ready Flow ${ }^{\mathrm{TM}}$ Reagent (Thermo Fisher, catalog number R37168). SYTOX is a high-affinity nuclei acid stain that is excluded from healthy cells but which penetrates cells with compromised plasma membrane. HS $(100 \mu \mathrm{g} / \mathrm{mL})$ was then added to pre-specified wells. One hour later, $50 \mu \mathrm{M}$ of $\mathrm{FeSO}_{4}$ was added to control or HS-exposed cultures. After $8 \mathrm{~h}$ in a $37^{\circ} \mathrm{C}$ incubator, the plate was taken for live cell imaging using the automated ImageXpress Micro XLS High-Content Analysis System under controlled environmental conditions $\left(37^{\circ} \mathrm{C}\right.$ and $\left.5 \% \mathrm{CO}_{2}\right)$. Images were taken at a prespecified location (center of well) every $30 \mathrm{~min}$ from 8 to $20 \mathrm{~h}$ (where zero is the time of addition of iron to the iron-containing wells). The images were then exported using the MetaXpressR software of ImageXpress into ImageJ. In ImageJ, images from each well were aligned and collated together chronologically as a video.

\subsection{Iron Chelation Analysis}

The capacity of HS to directly chelate iron was evaluated using the chrome azurol sulfate spectrophotometric assay, as described by others [53]. EDTA was used as a positive control. The ferrous ion-chelating (FIC) ability (\%) was obtained using the equation [(AcAs) $/ \mathrm{Ac}] \times 100$, where Ac is the absorbance of the control solution (containing all reagents except for the HS), and As is the absorbance in the presence of the HS (or EDTA) sample. 


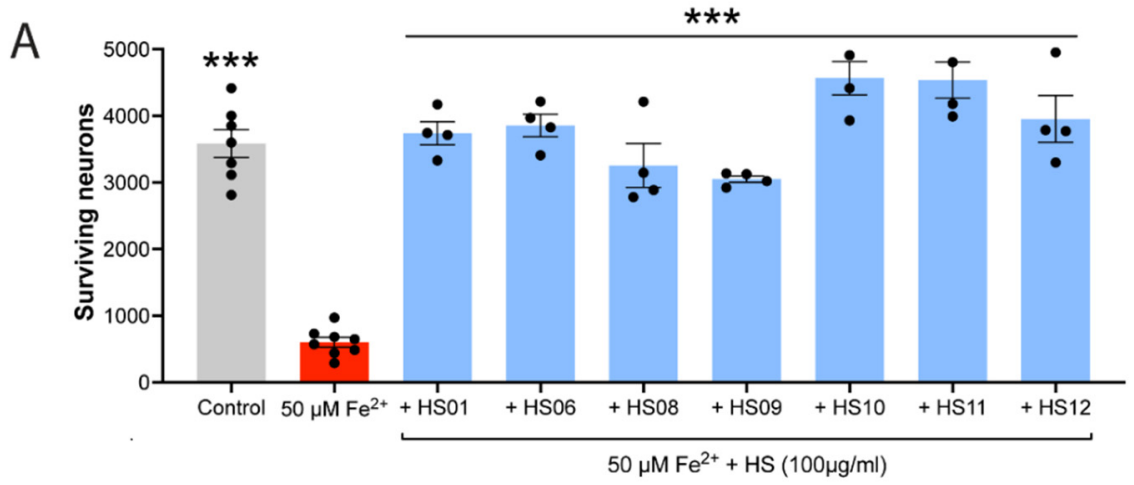

B
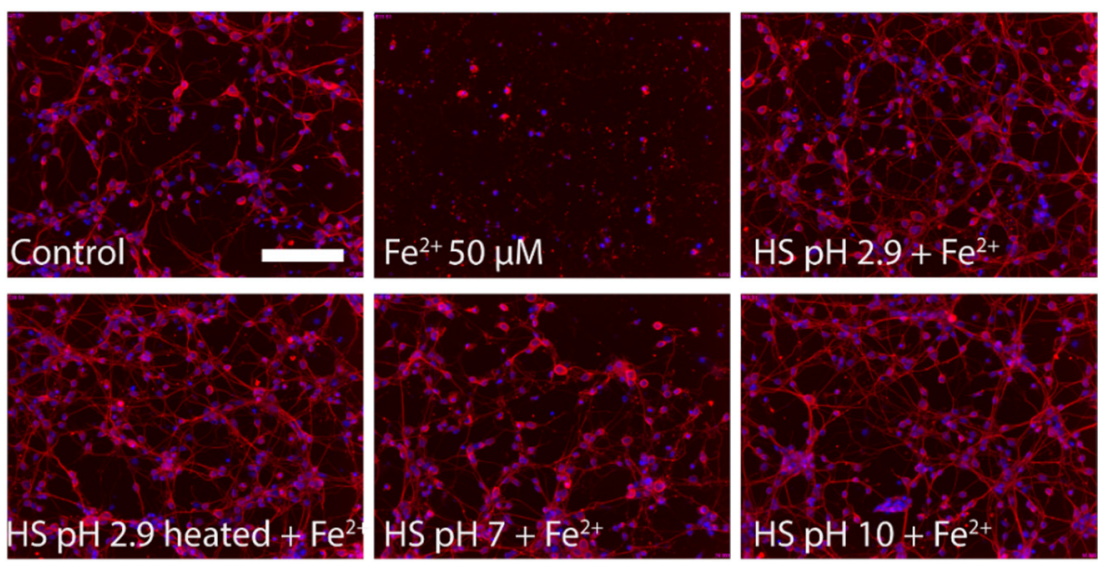

C

D
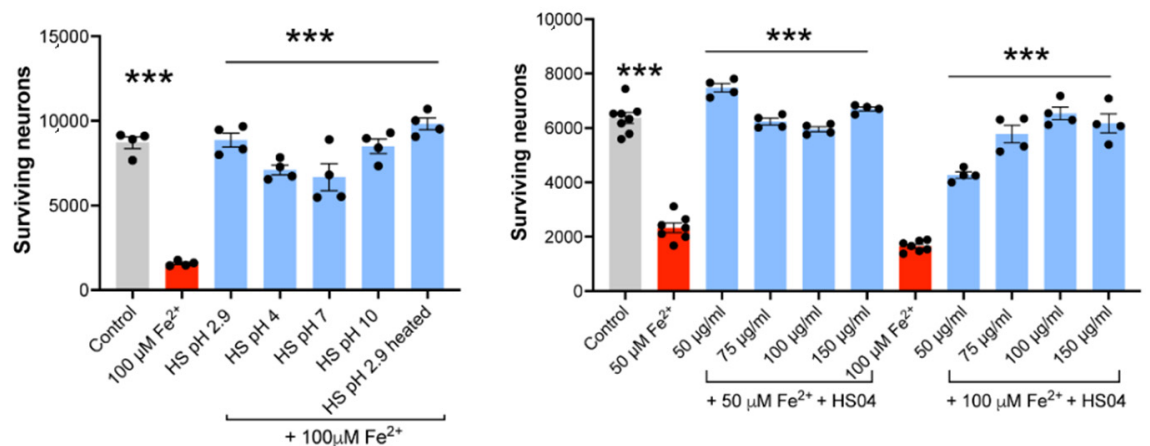

Figure 2. HS of varied $\mathrm{pH}$ protects against the iron-mediated killing of mouse neurons. (A) The killing of mouse neurons by iron is completely prevented by 7 different batches of HS extracts. All groups are different from iron alone: ${ }^{* *} p<0.001$ (1-way ANOVA with Dunnett multiple comparisons). $(\mathbf{B}, \mathbf{C})$ The protection of mouse neurons against iron toxicity by HS occurs despite the $\mathrm{pH}$ of HS being altered or HS being heated. Neurons are detected by Tuj1 staining (red), and all cells are labeled with DAPI (blue). The scale bar in the control group is identical across all 6 panels and represents $100 \mu \mathrm{m}$. Values are mean \pm SEM, with each dot representing a well. (D) Complete protection against iron neurotoxicity occurs from 50 to $150 \mu \mathrm{g} / \mathrm{mL} \mathrm{HS}$ when the iron concentration is $50 \mu \mathrm{M}$. When $\mathrm{FeSO}_{4}$ is raised to $100 \mu \mathrm{M}$, the $50 \mu \mathrm{g} / \mathrm{mL}$ HS is less but still highly effective in ameliorating neuronal death. *** $p<0.001$ (1-way ANOVA with Dunnett multiple comparisons) compared to iron.

\subsection{HORAC and ORAC Assays}

The hydroxyl radical antioxidant capacity (HORAC) and oxygen radical absorbance capacity (ORAC) assays were conducted using kits from Abcam (Toronto, ON, Canada). The catalog number for the HORAC assay kit was ab242299, while that for ORAC was ab233473. Values were displayed as gallic acid equivalent (GAE) and Trolox equivalent 
(TE), respectively. The assays were performed as detailed in the instructions provided by Abcam.

\subsection{Assessment of HS against Other Mediators of Neuronal Death}

We evaluated whether HS could protect against non-iron mediators of neuronal death. The exposure of neurons to amyloid beta and rotenone is used in models of Alzheimer's and Parkinson's disease, respectively $[54,55]$. The protein kinase $C$ inhibitor, staurosporine, at high concentrations kills cells through apoptosis [56]. Thus, neurons were exposed to $20 \mu \mathrm{M}$ of beta-amyloid peptide (1-42) (rPeptide), $10 \mu \mathrm{M}$ of rotenone (Sigma, Oakville, ON, Canada) or staurosporine (Sigma), with or $100 \mu \mathrm{g} / \mathrm{mL}$ HS that was applied $1 \mathrm{~h}$ before the toxins. Cells were harvested $24 \mathrm{~h}$ after and stained using a Tuj1 primary antibody as above.

\subsection{Proliferation of Splenocytes}

Murine splenocytes in 10\% fetal bovine serum-supplemented RPMI-1640 medium were labeled with $1 \mu \mathrm{M}$ of carboxyfluorescein succinimidyl ester (CFSE) dye, and HS was then added to specific groups. Cells $(100,000 /$ well) were then added to round-bottom wells in a 96-well plate that were uncoated (i.e., control, inactivated condition) or coated with $1 \mathrm{mg} / \mathrm{mL}$ anti-CD3/CD28 antibodies that activated T cells. After $72 \mathrm{~h}$, cells were subjected to flow cytometry (FACS Attune NXT) to measure CFSE dilution, where a more proliferative culture would have more cycles of diluted CFSE.

\subsection{EAE and Spinal Cord Histology}

All experiments were conducted with ethics approval from the Animal Care Committee at the University of Calgary under guidelines of the Canadian Council of Animal Care. Eight-to-ten-week-old C57BL/6 female mice (Charles River Laboratories, Montreal, QC, Canada) with an average weight of $22 \mathrm{~g}$ were immunized subcutaneously with $50 \mu \mathrm{g} / 100 \mu \mathrm{L}$ of myelin oligodendrocyte glycoprotein (MOG) 35-55 peptide (Protein and Nucleic acid facility, Stanford University, USA) in CFA supplemented with $4 \mathrm{mg} / \mathrm{mL}$ heatinactivated Mycobacterium tuberculosis H37Ra (Sigma). This method has been previously described [21,47]. A $50 \mu \mathrm{L}$ emulsion was deposited on either side of the tail base. Pertussis toxin (PTX) (300 ng/200 $\mu \mathrm{L}$, List Biological Laboratories, Campbell, CA, USA) was injected intraperitoneally on days 0 and 2 after MOG immunization. Daily monitoring of EAE mice was performed, and the mice were scored on a scale of 0 to 15 [47]. At tissue harvest, mice were killed with ketamine $(100 \mathrm{mg} / \mathrm{kg})$ and xylazine $(10 \mathrm{mg} / \mathrm{kg})$ intraperitoneally. A total of $15 \mathrm{ml}$ of PBS was then perfused via cardiac puncture followed by perfusion for $15 \mathrm{~min}$ of $4 \%$ paraformaldehyde in PBS. The spinal cord was removed, and the thoracic cord was collected into $4 \%$ paraformaldehyde for fixation overnight. Spinal cords were transferred to $30 \%$ sucrose solution for at least $48 \mathrm{~h}$ and were then frozen in FSC 22 Frozen Section Media (Leica, Buffalo Grove, IL, USA). Using a cryostat (Thermo Fisher), spinal cord tissue was cut longitudinally into $20 \mu \mathrm{m}$ sections, collected on to Superfrost Plus microscope slides (VWR) and stored at $-20^{\circ} \mathrm{C}$ prior to analysis.

For immunofluorescence staining, microscope slides containing spinal cord sections were warmed to room temperature for $10 \mathrm{~min}$. Samples were then rehydrated with PBS for $10 \mathrm{~min}$ and permeabilized with $0.2 \%$ Triton-X100 for $10 \mathrm{~min}$. Horse blocking solution (PBS, 10\% horse serum, 1\% BSA, $0.1 \%$ cold fish stain gelation, $0.1 \%$ Triton $\mathrm{X}-100,0.05 \%$ Tween-20) was used to block the sample for $1 \mathrm{~h}$ at room temperature. An additional step was conducted for MBP staining, where sections were delipidated by a successive wash of $50 \%, 70 \%, 90 \%, 95 \%, 100 \%, 95 \%, 90 \%, 70 \%$ and $50 \%$ ethanol prior to rehydration with PBS Primary antibodies used were rabbit anti-human/mouse IBA1 (1:1000, Wako, Richmond, VA, USA), mouse anti-human/mouse tubulin $\beta 3$ (1:500, Biolegend, San Diego, CA), rat anti-human CD45 (1:200, ThermoFisher), rat anti-mouse MBP (1:200, Abcam), and rabbit anti-mouse NF-H (Encor Biotechnology, Gainsville, CA, USA). Primary antibodies were applied overnight at $4{ }^{\circ} \mathrm{C}$. After washing, the following secondary antibodies (Jackson ImmunoResearch, Grove, PA, USA) were applied at 1:400 dilution of the commercial stock 
vial: Alexa Fluor 488 donkey anti-mouse IgM, Alexa Fluor 647 donkey anti-mouse IgM, Alexa Fluor 488 donkey anti-mouse IgG, Cyanine Cy3 donkey anti-rat IgG, Alexa Fluor 488 donkey anti-rabbit IgG and Alexa Fluor 647 donkey anti-rabbit IgG.

Fluorescence images of entire longitudinal sections were acquired on an Olympus VS120 Virtual Slide Scanner with a $20 \times$ objective (0.75NA PlanApo aperture) and at fixed camera exposure for each fluorescent probe. All images were processed and analyzed using ImageJ (National Institutes of Health, Bethesda, MD, USA) as reported elsewhere [57]. Images were first converted from 16 bit to 8 bit and split into separate fluorescence channels corresponding to each marker. The polygon tool was used to define the white matter as the region of interest (ROI), while grey matter was cleared and excluded from the analysis. For each channel, a separate intensity threshold was determined, such that positive cells were identified, and applied to segment all images. The segmented images were taken to determine the area fraction of positive cells for each marker. This quantitative method was recently detailed [57].

It would be of importance to assess changes to neurotransmitter systems in EAE and to determine whether these are rescued by HS. However, EAE is unpredictable in the location of lesions in the spinal cord, and EAE neuropathology is affected differently from one mouse to the next, so that it would be difficult to accurately and reliably assess the changes to neurotransmitters in an EAE experiment. For this reason, we developed quantitative axonal counts through the white matter of the entire thoracic cord [57], so that changes to axonal perturbation from one mouse to another could be meaningfully captured across a large area of the spinal cord in an experiment.

\subsection{Statistical Analysis}

Data were collated in Microsoft Excel. Graphs were generated using GraphPad Prism 8 (GraphPad, LaJolla, CA, USA). Data shown are the individual data points, where each point on a bar graph represents a biological replicate (for in vivo experiments) or replicate (for in vitro experiments) and mean +/ - SD. A $t$-test was used to compare between 2 groups. Unless otherwise stated, one-way ANOVA with Dunnett's multiple comparison test was used to analyze statistically significant differences between the means of two or more treatment groups against the control group. Asterisks indicate significance, where ${ }^{*} p<0.05$, ${ }^{* *} p<0.01$ and ${ }^{* * *} p<0.001$.

\section{Results}

3.1. The Killing of Human Neurons in Culture by Iron Is Attenuated by HS, and This Is Not Due to Direct Iron Chelation

Figure $1 \mathrm{~A}$ is a schematic of the nine fields of view that were automatically imaged per well to represent the total number of neurons remaining after $24 \mathrm{~h}$ in that well. Figure 1B captures a low-magnification image of control neurons, neurons exposed to iron for $24 \mathrm{~h}$, and neurons treated with a representative HS and iron. This provides a visual example that the substantial loss of neurons caused by iron exposure is protected by HS.

Human neurons are highly susceptible to killing by $50 \mu \mathrm{M}$ of ferrous iron in culture [21]. Exposure to $50 \mu \mathrm{M}$ of $\mathrm{FeSO}_{4}$ for $24 \mathrm{~h}$ resulted in the obvious loss of neurons (Figure 1C). However, in the presence of HS at 75-600 $\mu \mathrm{g} / \mathrm{mL}$, which were concentrations that were empirically chosen to span a range, human neurons survived the iron exposure. Complete neuroprotection was achieved by 150-600 $\mu \mathrm{g} / \mathrm{mL}$ HS (Figure 1D).

We assessed the capacity of HS to directly chelate iron and found no evidence of this capacity even at a very high concentration $(3 \mathrm{mg} / \mathrm{mL})$ of HS. In contrast, the positive control EDTA had robust iron chelation activity (Figure 1E).

\subsection{Mouse Neurons Are Also Protected by HS against Iron Neurotoxicity in Culture}

Because of the limited supply of primary human neurons, we cultured mouse neurons to corroborate the human results. Figure 2A,B demonstrate that mouse neurons in culture 
were also highly susceptible to iron-induced killing. Seven separate extractions of HS tested at $100 \mu \mathrm{g} / \mathrm{mL}$ each completely neutralized iron neurotoxicity (Figure 2A).

If administered in vivo, HS is likely to encounter different $\mathrm{pHs}$ in the body, for example, a $\mathrm{pH}$ of 4 at the upper part of the stomach and a lower $\mathrm{pH}$ in the bottom half. Moreover, the $\mathrm{pH}$ of blood is about 7.4. Thus, we made HS solutions of different $\mathrm{pHs}$ by increasing the $\mathrm{pH}$ of stock $\mathrm{HS}$ ( $\mathrm{pH} 2.9$ ) to 4,7 or 10 using drops of $1 \mathrm{~N} \mathrm{NaOH}$. Moreover, the stock HS ( $\mathrm{pH}$ 2.9) was heated for $1 \mathrm{~h}$ at $90{ }^{\circ} \mathrm{C}$ and then allowed to cool to room temperature. These were then tested to determine if they could protect against iron toxicity. Figure $2 \mathrm{~B}, \mathrm{C}$ show that regardless of the $\mathrm{pH}$ of the solutions, and despite heating, HS ameliorated iron toxicity on mouse neurons.

A concentration response of HS was next assessed against 50 or $100 \mu \mathrm{M}$ of $\mathrm{FeSO}_{4}$. Against the lower concentration of iron, HS from 50 to $150 \mu \mathrm{g} / \mathrm{mL}$ completely protected mouse neurons against $50 \mu \mathrm{M}$ of $\mathrm{FeSO}_{4}$. Against the higher $100 \mu \mathrm{M}$ of $\mathrm{FeSO}_{4}, \mathrm{HS}$ at $50 \mu \mathrm{g} / \mathrm{mL}$ was partially protective, but higher concentrations of HS afforded complete protection (Figure 2D).

\subsection{Life Imaging of Neurons}

Supplementary Video S1 shows a control mouse neuronal culture without $\mathrm{HS}$ or $\mathrm{FeSO}_{4}$ exposure. From 8-20 h, few of the CMTPX-labeled cells (which marks all cells) were SYTOX (green)-positive. As noted in the Methods, SYTOX only crosses into cells with a disrupted plasma membrane. In contrast, in cultures exposed to $\mathrm{FeSO}_{4}$, the number of cells that turned green progressively increased, and this was strikingly prevented by HS.

\subsection{HS Is Superior to MS Medications for Neuroprotection against Iron}

Medications used to treat MS are based on their capacity to reduce the dysregulated immune system in MS [58]. However, with the recognition that MS involves the substantial degeneration of neurons and axons that drives the progression of disability [6,8], there has been interest in whether MS medications have direct capacity to protect neurons. In this regard, dimethylfumarate (and also its metabolite monomethylfumarate (MMF), to which dimethylfumarate is rapidly converted in vivo) has been shown in culture to protect against the $\mathrm{H}_{2} \mathrm{O}_{2}$ - or amyloid-beta-induced death of neurons through an Nrf2-dependent pathway $[59,60]$, while fingolimod protects neurons against oxidative stress or glutamate excitotoxicity by activating sphingosine-1-phosphate receptors [61,62]. Another drug, laquinimod, reduces brain atrophy in patients with MS $[63,64]$ and has protective effects on neurons against various insults $[50,65]$, although it has not received regulatory approval for use in MS. Whether these could protect against iron neurotoxicity has not been addressed. Thus, we compared the potency of HS against these MS medications.

Human neurons were exposed first to HS, MMF, fingolimod or laquinimod, and this was followed $1 \mathrm{~h}$ later by $\mathrm{FeSO}_{4}$. Twenty-four hours later, the number of surviving neurons was evaluated. Figure 3A shows that none of the MS medications at concentrations used in the literature protected neurons against iron neurotoxicity, while HS $(100 \mu \mathrm{g} / \mathrm{mL})$ was effective.

Siponimod is another MS medication with perceived activity within the CNS of MS patients [8]; indeed, it is an approved medication for active secondary progressive MS, which has marked neurodegenerative processes. In tissue culture, siponimod protects neurons against astrocyte-induced toxicity [66]. The intraventricular infusion of siponimod in the EAE model of MS prevents synaptic degeneration and preserves neurons [67]. However, when tested against iron in culture, siponimod was ineffective in conditions in which HS was completely protective (Figure 3B). 

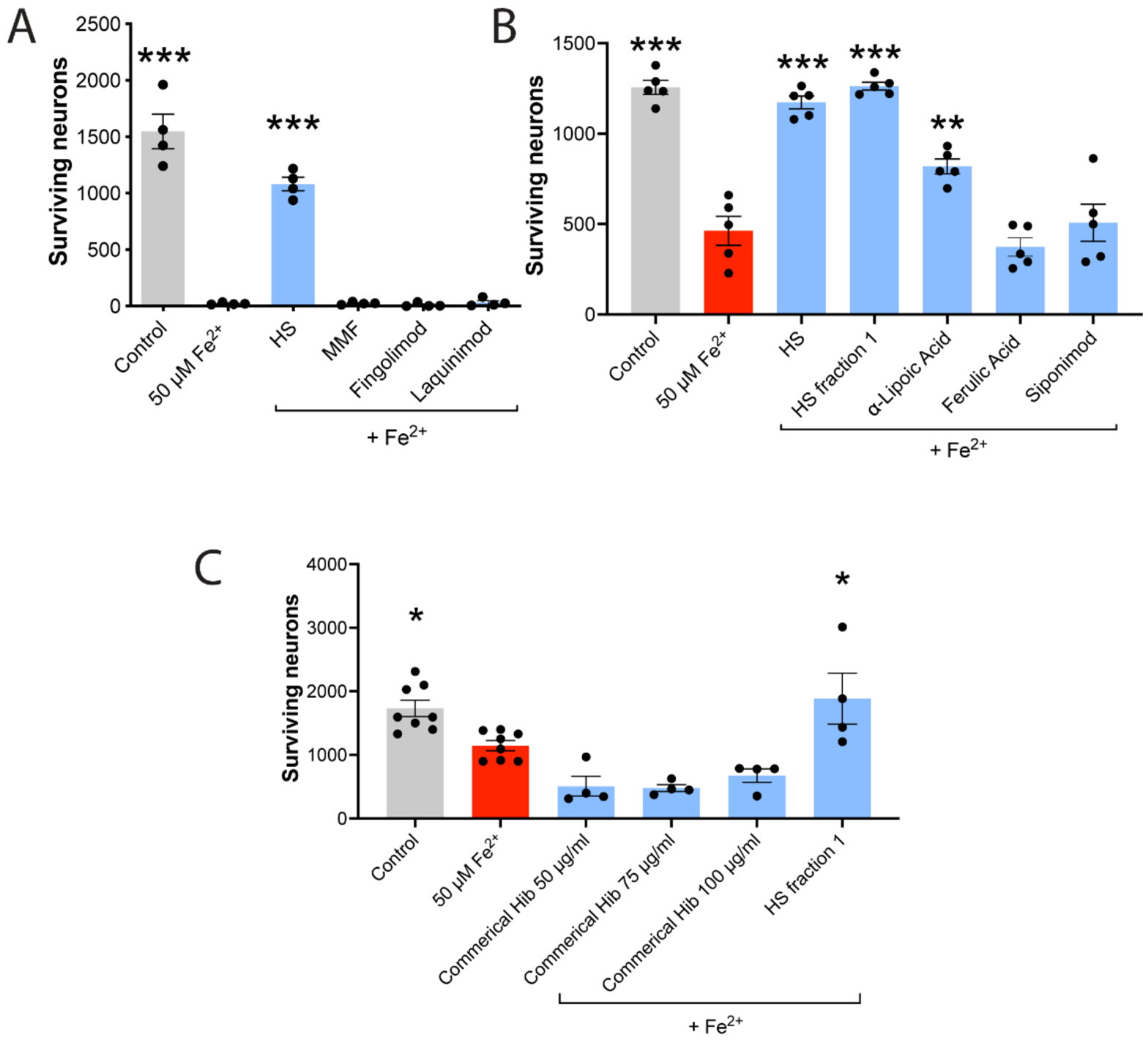

Figure 3. HS protection against iron neurotoxicity is not mimicked by MS medications or a commercial hibiscus extract and is not proportional to anti-oxidant activity. (A) The loss of neurons caused by $50 \mu \mathrm{M}$ of $\mathrm{FeSO}_{4}$ is ameliorated by HS $(100 \mu \mathrm{g} / \mathrm{mL})$ but not by MMF $(100 \mu \mathrm{M})$, fingolimod (FTY-720P, $100 \mathrm{nM})$ or laquinimod $(5 \mu \mathrm{M})$. These concentrations of drugs used in MS are congruent with reported concentrations for neuroprotection against other stressors in the literature. (B) HS (100 $\mu \mathrm{g} / \mathrm{mL})$ and its fraction $1(80 \mu \mathrm{g} / \mathrm{mL})$ completely overcome iron toxicity, while the strong anti-oxidant ferulic acid $(5 \mu \mathrm{g} / \mathrm{mL})$ or the MS medication siponimod $(1 \mathrm{nM})$ are ineffective. ${ }^{* * *} p<0.001$ (1-way ANOVA with Dunnett multiple comparisons) compared to $\mathrm{FeSO}_{4}$. Alpha lipoic acid $(50 \mu \mathrm{g} / \mathrm{mL})$ partially ameliorates killing of neurons by iron. (C) The commercial hibiscus from 50 to $100 \mu \mathrm{g} / \mathrm{mL}$ does not protect iron neurotoxicity unlike the positive control, HS fraction 1. All values are mean \pm SEM, with each dot representing a well. ${ }^{*} p<0.001,{ }^{* *} p<0.01,{ }^{* * *} p<0.001$ (1-way ANOVA with Dunnett multiple comparisons) compared to iron.

\subsection{Neuroprotection against Iron Is Not Related to Anthocyanin Content}

Many plant products have high anthocyanin content, and anthocyanins can have neuroprotective activities [68], although high levels are also toxic [44]. We evaluated the total anthocyanin content of HS and found relatively low levels $(3.16 \pm 0.28 \mathrm{mg} / \mathrm{g}$, mean \pm SEM across eight different HS extracts) compared to the commercial hibiscus capsule $(9.04 \mathrm{mg} / \mathrm{g})$. HS fraction 1 had no measurable anthocyanin content. Other differences in chemical constituents might exist between HS fraction 1 and commercial hibiscus, but we did not document these. When evaluated against the iron-mediated killing of neurons, HS 
fraction 1 completely protected neurons, while the commercial hibiscus (50-100 $\mu \mathrm{g} / \mathrm{mL}$ ) was devoid of an iron neuroprotection capacity (Figure 3C).

\subsection{Neuroprotection against Iron Is Not Proportional to Anti-Oxidant Activity}

We evaluated the capacity of HS to scavenge and prevent hydroxyl radical degradation of fluorescein in the HORAC assay, using gallic acid equivalent (GAE) to inform on the HORAC activity of 10 separate HS preparations. The mean HORAC activity was 575 $\mu$ mole/g (Table 1), while that of the commercial hibiscus exceeded the standard curve $(>800 \mu \mathrm{mole} / \mathrm{g})$. HS fraction 1 had no measurable HORAC activity. For scavenging of peroxyl radical, using the ORAC assay, HS but not its fraction 1 had activity. The HORAC and ORAC activity thus did not predict the iron neuroprotection, as HS and HS fraction 1 protected neurons but the commercial hibiscus could not (Figure 3B,C and Table 1).

Table 1. The HORAC and ORAC activities do not predict protection against neuronal killing.

\begin{tabular}{cccc}
\hline Sample & $\begin{array}{c}\text { HORAC } \\
(\mu \mathrm{mole} / \mathrm{g})\end{array}$ & $\begin{array}{c}\text { ORAC } \\
(\mu \mathrm{mole} / \mathrm{g})\end{array}$ & $\begin{array}{c}\text { Relative Protection } \\
\text { against Iron Killing } \\
(\mathbf{\%})\end{array}$ \\
\hline HS & $\begin{array}{c}575 \pm 75 \\
(10 \text { extracts })\end{array}$ & $\begin{array}{c}480 \pm 45 \\
(3 \text { extracts })\end{array}$ & 100 \\
\hline Commercial hibiscus & $>800$ & Not determined & 0 \\
\hline HS Fraction 1 & 0 & 0 & 100 \\
\hline Alpha lipoic acid & 848 & 300 & $\sim 50$ \\
\hline Ferulic acid & 4549 & 7451 & 0 \\
\hline
\end{tabular}

Further unexpected separation of anti-oxidant activity from iron neuroprotection was evident by ferulic acid, a very strong anti-oxidant [69]. Indeed, ferulic acid had HORAC and ORAC activities that were over 10-fold those of HS (Table 1), but it failed to block the killing by iron of neurons (Figure 3B).

Finally, we examined alpha lipoic acid [31,70,71], an anti-oxidant being tested in a Phase 2 clinical trial in progressive MS (ClinicalTrials.gov Identifier: NCT03161028), where it reduced brain atrophy in a previous Phase 2 clinical trial of patients with secondary progressive MS [32]. Table 1 shows that alpha lipoic acid was comparable in HORAC and ORAC activities with HS. Notably, while HS completely prevented iron toxicity, alpha lipoic acid at $50 \mu \mathrm{g} / \mathrm{mL}$ was only partially effective (Figure 3B). Lower concentrations of alpha lipoic acid from $1-5 \mu \mathrm{g} / \mathrm{mL}$ did not confer any protection (data not shown). In MS patients taking $1200 \mathrm{mg}$ alpha lipoic acid, the dose in MS clinical trials, the median peak level of alpha lipoic acid in the serum was $4.8 \mu \mathrm{g} / \mathrm{mL}$ [72].

\subsection{HS Also Protects Neurons against Other Stressors}

The mechanism(s) by which HS protects neurons against iron toxicity is unknown, as the above data suggest a separation of anti-oxidant activity from iron neuroprotection in the conditions tested. It is possible that particular HS constituents, alone or in combination, alter properties within neurons that enable the cells to protect against subsequent toxin exposure. To support this hypothesis, we pretreated neurons with HS $(100 \mu \mathrm{g} / \mathrm{mL})$ for $1 \mathrm{~h}$ and then exposed them to beta-amyloid $(20 \mu \mathrm{M})$, rotenone $(10 \mu \mathrm{M})$ or staurosporine $(200 \mathrm{nM})$. After $24 \mathrm{~h}$, few neurons remained in toxin-exposed cultures, but this loss was attenuated by HS (Figure 4). In comparison, neurons pretreated for $1 \mathrm{~h}$ with monomethylfumarate or laquinimod did not reduce the toxicity of beta-amyloid, rotenone or staurosporine. Fingolimod did not counter the killing of neurons by rotenone or staurosporine, but it decreased the toxicity of beta-amyloid, as has been reported by others [73]. 

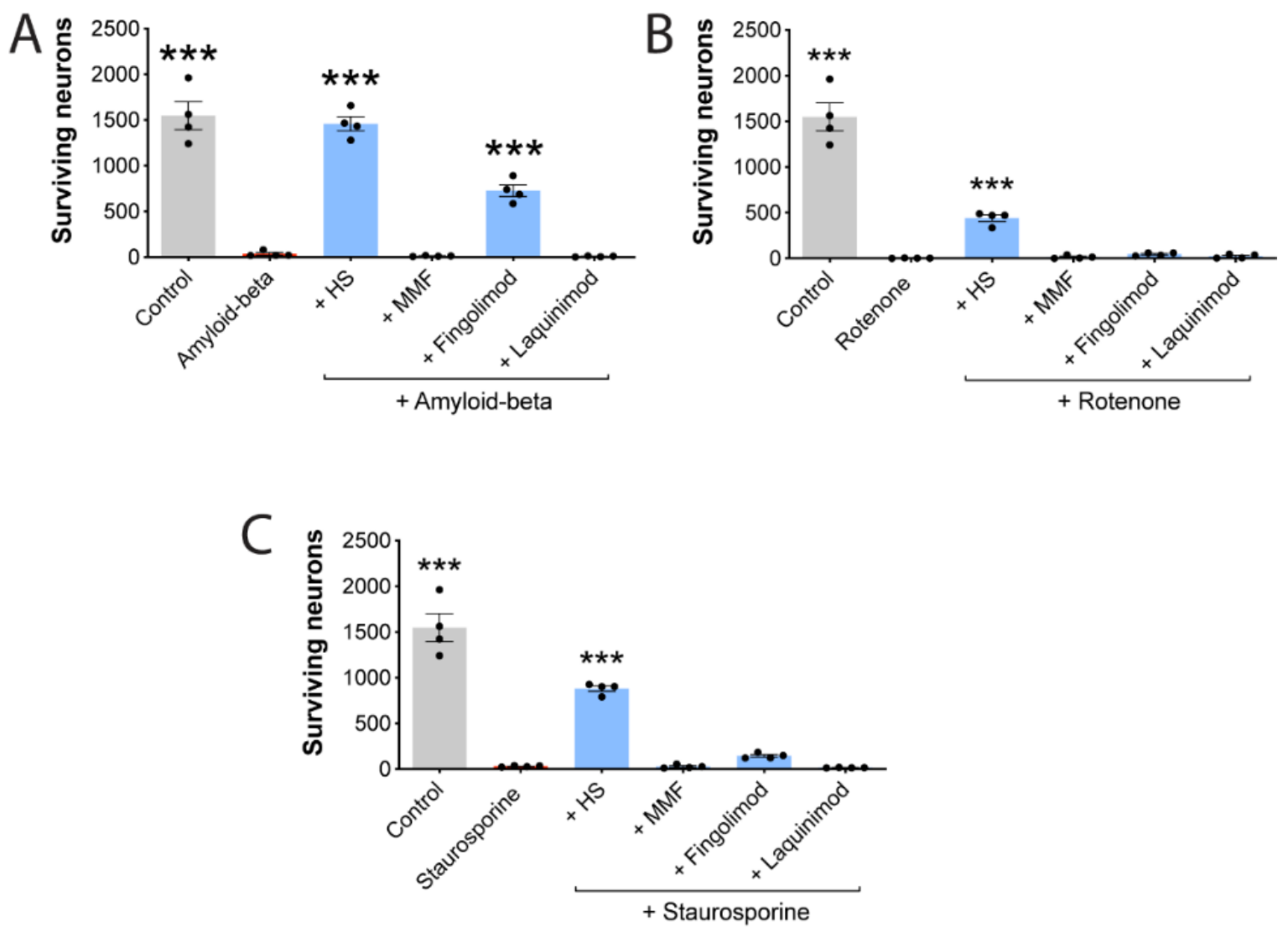

Figure 4. HS protects against other mediators of injury. Neurons were exposed to HS and the test medications for $1 \mathrm{~h}$ prior to amyloid-beta $(20 \mu \mathrm{M})(\mathbf{A})$, rotenone $(10 \mu \mathrm{M})(\mathbf{B})$ or staurosporine $(200 \mathrm{nM})$ (C). Cells were harvested $24 \mathrm{~h}$ after for neuronal counts. HS was used at $100 \mu \mathrm{g} / \mathrm{mL}$, while MMF was tested at $100 \mu \mathrm{M}$, fingolimod (FTY-720P) at $100 \mathrm{nM}$ and laquinimod at $5 \mu \mathrm{M}$. All values are mean \pm SEM, with each dot representing a well. ${ }^{* * *} p<0.001$ compared to the toxins alone (1-way ANOVA with Dunnett multiple comparisons).

\subsection{HS Does Not Affect the Proliferation of T Cells in Culture}

We investigated whether HS affects the activity of $\mathrm{T}$ lymphocytes since the overactivation of pro-inflammatory T cells helps drive inflammatory conditions such as MS [74,75], and disease-modifying therapies used in MS have potent effects on T cells [58]. Murine splenocytes were subjected to no activation, or to polyclonal (anti-CD3/anti-CD28) activation, with or without HS treatment. After 72 h, CFSE dilution was measured using flow cytometry, where a more proliferative culture would have more cycles of diluted CFSE. Figure 5 shows that polyclonal activation increased the cycles of CFSE dilution (number of humps to the left of the tall peak), but this was not reduced by HS from $75-300 \mu \mathrm{g} / \mathrm{mL}$.

\subsection{HS Reduces the Severity of Murine EAE and Confers Neuroprotection In Vivo}

We tested the efficacy of HS (whole HS extract as used in Figure 1) in mice immunized to develop EAE. On the day of immunization, HS was initiated once a day at $250 \mathrm{mg} / \mathrm{kg}$ by oral gavage. Seven immunized mice were administered HS, while five mice received vehicle (water). Mice in the vehicle group manifested clinical signs from day 13 and were increasingly sick: initially this manifested as a limp tail, then they additionally acquired hind limb followed by forelimb paresis, which was close to paralysis in some cases (Figure 6A). All five vehicle mice were sick. In mice with HS, five of seven mice did not show EAE clinical signs, while one had breakthrough vehicle-level EAE. The last had mild disease. The average of the disability scores in the HS group amounted to one on a fifteen-point scale, which represents mild tail disability (i.e., no limb involvement) 
(Figure 6A). Supplementary Video S2 displays the movement of a representative (based on the average disability score) mouse in the vehicle or HS groups just before the termination of the experiment on day 24. While the vehicle-EAE mouse had tail disability (i.e., not raised from the ground) and obvious hind limb impairment, the HS-EAE appeared normal with the exception of the tail being on the ground.

A
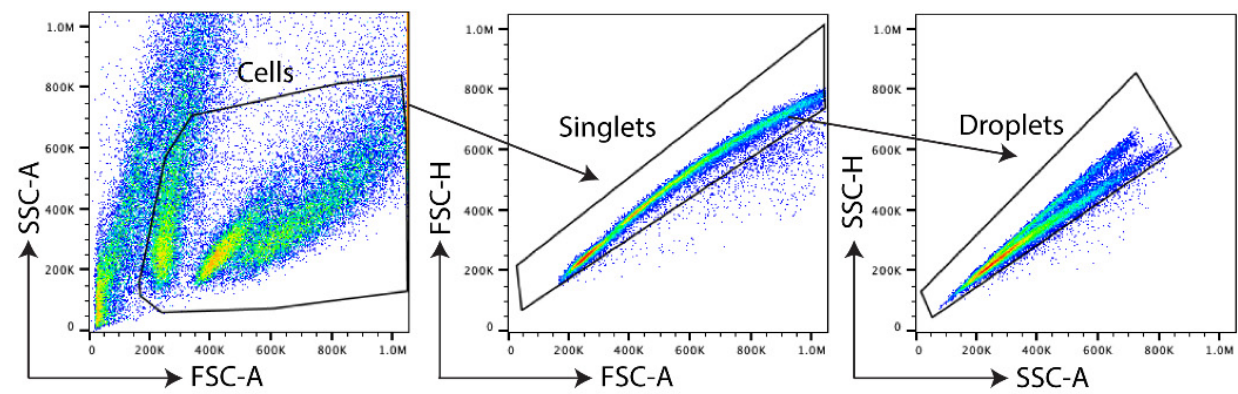

B
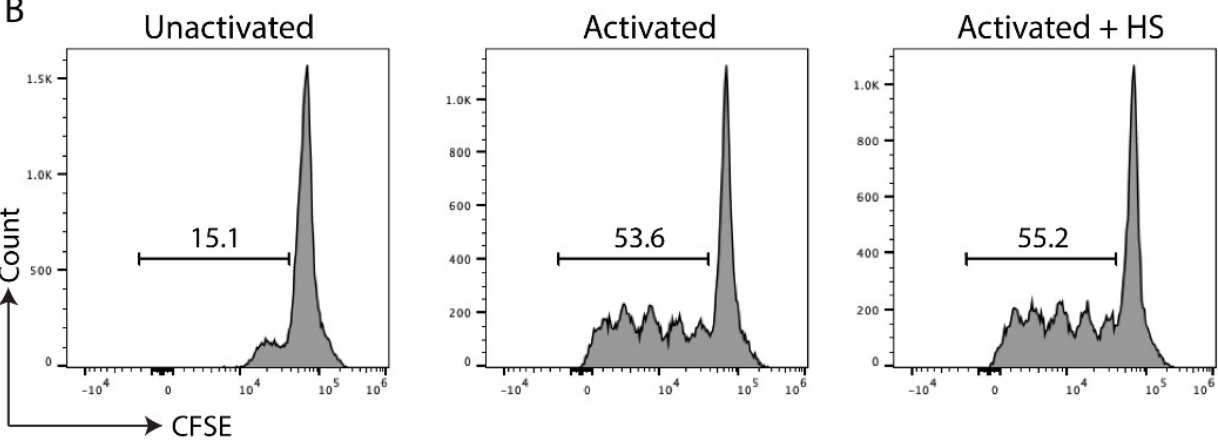

C

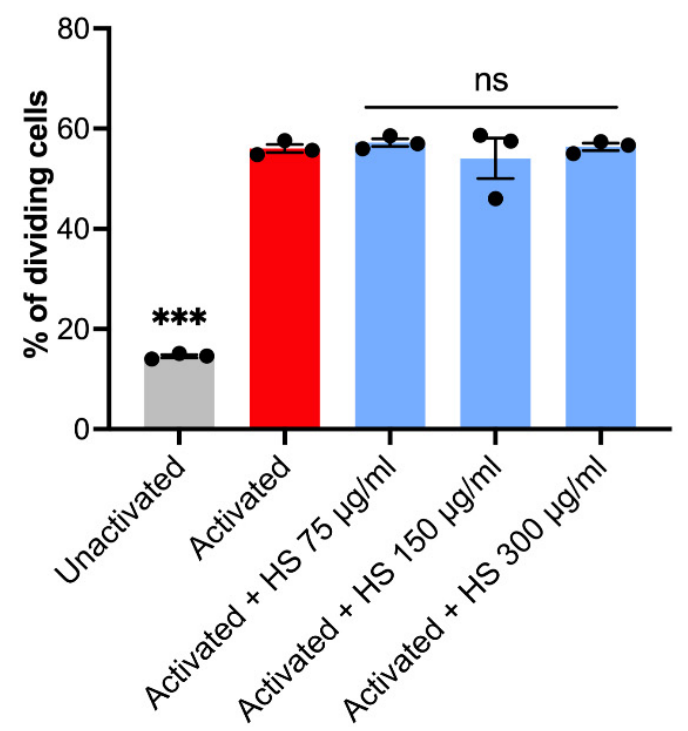

Figure 5. HS does not reduce the proliferation of T cells in culture. (A) FACS plots showing how the cells are evaluated. (B) CFSE plots where the humps to the left of the tall peak represent cycles of cell division. The $\%$ of dividing cells is also displayed. (C) Mean \pm SEM of triplicate experiments. *** $p<0.001$ (1-way ANOVA with Dunnett multiple comparisons) compared to activated controls. ns: not significant different from activated controls. 


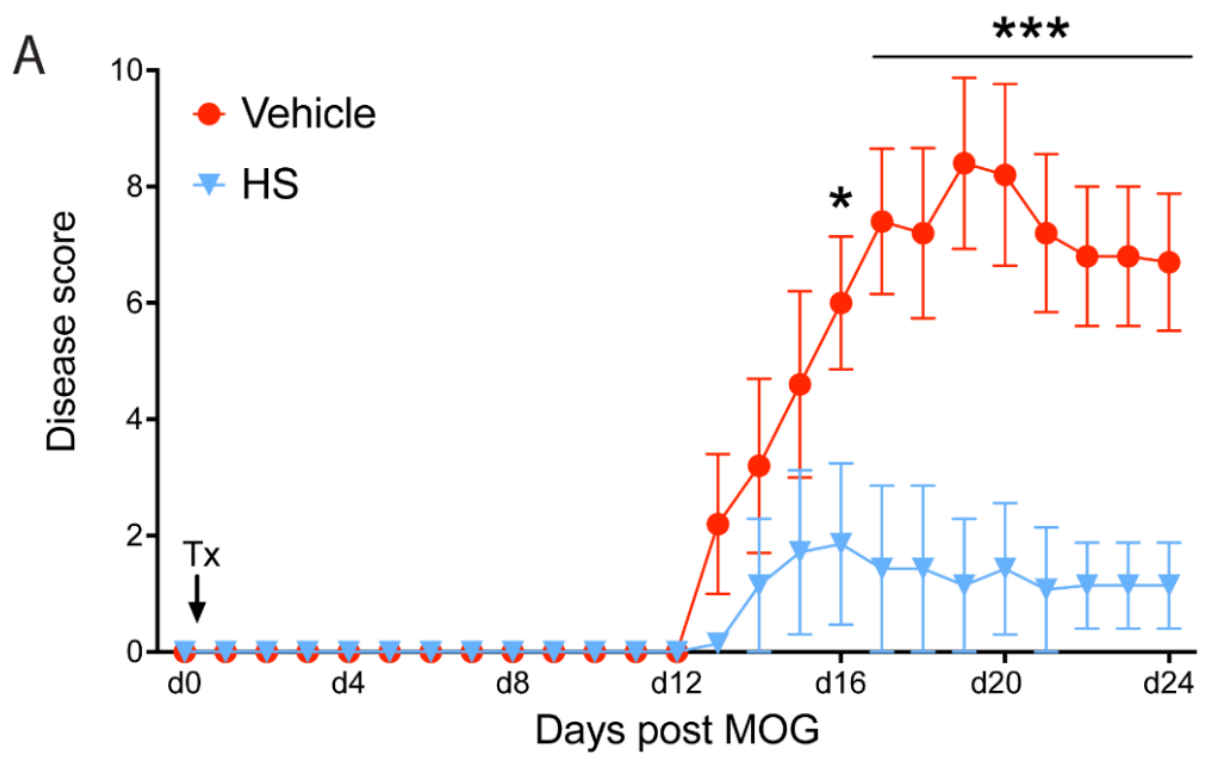

B
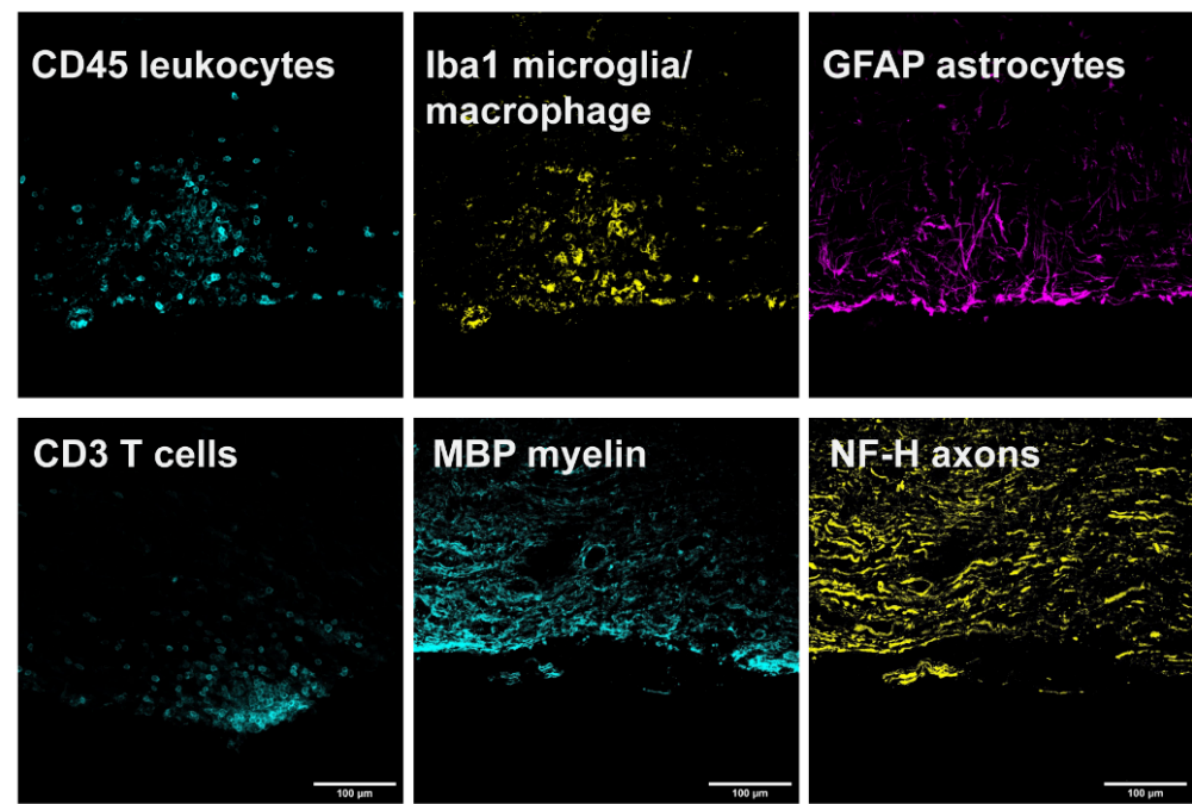

Figure 6. Oral HS treatment of mice immunized for EAE attenuates clinical disability. (A) While all 7 mice treated with vehicle develop severe EAE, this is significantly attenuated when mice are treated with HS (n of 5 mice). ${ }^{*} p<0.05,{ }^{* * *} p<0.001$ (two-way ANOVA with repeated measures). Treatment initiation of the daily oral gavage is indicated by ' $\mathrm{Tx}^{\prime}$. Please see Supplementary Video S2 for the disability in mice representative of both groups. (B) Longitudinal thoracic sections of the spinal cord are stained for the various markers, and here, high-magnification images are displayed of a lesion (hypercellularity) of leukocytes (CD45+), some of which are CD3+ T cells and Iba1+ macrophages, along with microglia/macrophages (Iba1+), and reactive astrocytes (GFAP+); the respective colors are defined by the words in each panel. The edge of the tissue is at the bottom part of each panel. Disruption of $\mathrm{MBP}+($ myelin basic protein + ) myelin and NFH+ (neurofilament heavy chain) axons can be seen in that lesion. Scale bar is $100 \mu \mathrm{m}$.

Mice were killed at day 24, and the spinal cord was processed for histological assessments of neuropathology. Figure 6B displays examples of stains in longitudinal sections of the spinal cord of EAE mice (vehicle treatment). An active lesion is informed by an aggregate of CD45+ leukocytes, some of which are CD3+ T cells and Iba1+ microglia/macrophages. As CNS lesions in EAE can vary in size and location, we quantified 
the histological outcomes by evaluating the thoracic spinal cord in longitudinal sections for each mouse. Figure 7A shows examples of longitudinal sections used for quantitation. The images are from a vehicle-treated EAE spinal cord stained for CD45 (immune cells), CD3 (T cells) or Iba1 (microglia/macrophages), or for the degree of myelin (myelin basic protein, $\mathrm{MBP}+$ ) or axonal (neurofilament heavy chain, NFH) loss. Sections with a central canal were chosen for quantification to normalize location across mice. For quantitation, slide scanner images of both the right and left lateral columns were processed by ImageJ software for the total area per section bordered by the stain of interest, as described recently [57]. Of this, the area and thus the \% covered by the thresholded stain was then obtained. In addition to the EAE-vehicle (control) or EAE-HS groups, naïve mice with no EAE induction were also assessed.
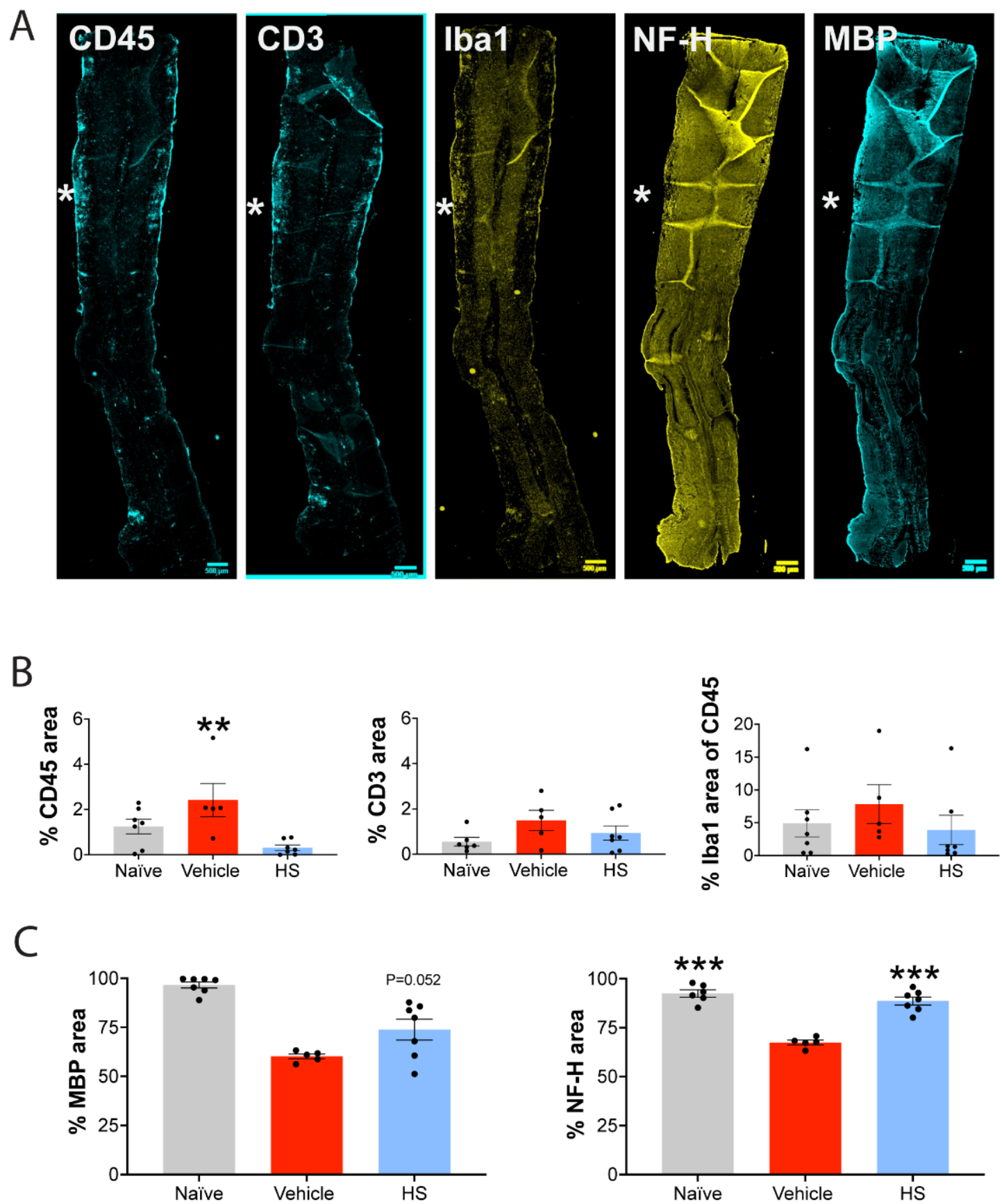

Figure 7. HS treatment prevents axonal loss in EAE. (A) Longitudinal thoracic spinal cord sections displayed with an active lesion indicated by *. Scale bar is $500 \mu \mathrm{m}$. These longitudinal sections were 
used for analysis of the spinal cord covered by a particular stain. (B) Quantitation of the extent of neuroinflammation (CD45 for immune cells; CD3 for T cells; Iba1 for microglia/macrophage) in the spinal cords of control-EAE or HS-treated EAE mice, killed at day 24 (from the experiment of Figure 6). ${ }^{* *} p<0.01$ (2-tail unpaired $t$-test). (C) Quantitation of the extent of myelin (MBP) and axonal (NFH) preservation in the spinal cord of EAE mice treated with HS. Naïve mice referred to as spinal cords from unmanipulated animals. ${ }^{* * *} p<0.001$ compared to EAE-vehicle control (1-way ANOVA with Dunnett multiple comparisons).

Figure 7B shows that the degree of CD3 T-cell neuroinflammation was not different across the groups, corroborating the tissue culture data that HS does not direct affect T-cell proliferation. In contrast, the CD45 immunoreactivity, which encompassed all leukocytes and also microglia, was shown to be reduced by HS compared to control-EAE.

Finally, we evaluated the extent of myelin and axonal loss in the lateral columns using immunoreactivity for MBP and neurofilament, respectively. While the myelin loss occurring in EAE was not affected by HS ( $p=0.052$ comparing control-EAE versus HS-EAE in the ANOVA Dunnett multiple comparisons), the prominent loss of axons in EAE-control was significantly prevented by HS (Figure 7C). Remarkably, the axonal density in the lateral columns of the thoracic spinal cord in EAE mice treated with HS was similar to that of naïve controls. Thus, HS is neuroprotective against the neuroaxonal loss that occurs after EAE injury.

\section{Discussion}

The neuropathology of MS includes the loss of oligodendrocytes and myelin and of neurons and their axons. The latter neuroaxonal injury and loss correlates with neurologic disability in MS, as evaluated using MRI and postmortem histology studies [76,77], and is thought to drive the progression of disability. Other debilitating symptoms of MS, including cognitive impairments that occur from early in MS, also correlate with brain atrophy [78]. Indeed, much data affirm that the neuroaxonal injury and loss occur earlier in the disease before formal diagnosis. Atrophy is observed in radiologically isolated syndrome (RIS), which is the earliest detection via MRI of possible future MS and where $\sim 50 \%$ of subjects are diagnosed with MS within 10 years [4]. Atrophy is observed in RIS in the spinal cord [79], thalamus [80] and cerebellum [3]. For clinically isolated syndrome, which is the first clinically documented demyelinating event and where a second episode would lead to the diagnosis of MS, there is extensive gray matter atrophy in several brain areas $[77,81]$. Another index of neuroaxonal degeneration is the MR spectroscopy-detected reduction in brain $\mathrm{N}$-acetylaspartate normalized to creatine. This ratio is lower in several brain regions in RIS compared to controls [82]. Conversely, a rise in serum levels of neurofilament-light (NFL) chain reflects neurodegeneration. NFL is released upon neuroaxonal injury into the blood stream, and its increase in blood occurs from RIS [83,84]. Thus, to slow the progression of MS pathology and disability, treatment to protect axons and neurons must be initiated very early.

To slow the neuropathology of MS, an understanding of the mediators of injury is required. These mediators include secretory products of immune cells such as cytokines and proteases [6,85,86], mitochondrial injury [87], glutamate excitotoxicity [88,89] and oxidative stress. The presence of oxidative stress in MS lesions is well reviewed [90,91] and informed by the presence in lesions of lipid peroxides and their breakdown aldehydes such as malondialdehyde and 4-hydroxy-2-nonenal, and by oxidized DNA including 8-hydroxy2'-deoxyguanosine. Van Horssen et al. [92] found that these markers were elevated in active demyelinating lesions, while Nikic et al. [93] associated reactive oxygen and nitrogen species with focal axonal degeneration. In general, oxidative stress is commonly observed in active MS lesions of both the gray and white matter [29]. This is compounded by the decline in anti-oxidant enzymes that detoxify free radicals [94], and by a decrease in the thiol glutathione $[95,96]$ over the course of MS. There is a need for anti-oxidants that 
penetrate into the brain in MS, and this is the basis of clinical trials with alpha lipoic acid in MS [32]. Dimethylfumarate used in MS to control aberrant lymphocyte activity activates the transcriptional activator Nrf2 [97] that lies upstream of many anti-oxidant enzyme systems. Whether this contributes to its efficacy in MS is unknown.

Another mediator of injury that is increasingly appreciated in MS is iron. Its accumulation noted from early MS is detailed in the Introduction. The source of iron accumulation in MS brains is still unclear, but oligodendrocytes are known to be a major cell type that accumulate iron, since iron is an important cofactor for several enzymes in myelin synthesis $[7,98,99]$. In the human brain, iron is also stored in ferritin in myelin sheets [100]. Upon the destruction of oligodendrocytes and myelin, iron is released extracellularly and can be phagocytosed by microglia and macrophages [28]. If these myeloid cells degenerate, there can be an additional wave of iron deposition and associated oxidative stress [101]. The neurotoxicity of iron is likely exacerbated by the reduced level of the ferroptosis inhibitor, glutathione peroxidase-4, in the gray matter of MS brains [102]. The toxicity of ferrous iron involves oxidative stress, with the highly reactive hydroxyl radical formed from the Fenton reaction of ferrous iron with $\mathrm{H} 2 \mathrm{O} 2$. However, iron is also destructive through other mechanisms, including ferroptosis [12,13], activating sphingolipid death pathways [16], and in misfolding proteins that compromise cells [17-20].

Despite the toxicity of iron, none of the disease-modifying therapies used in MS are known to affect iron homeostasis. Herein, we unexpectedly found that extracts of HS applied to human or mouse neurons in culture protected against iron neurotoxicity, and that HS attenuated axonal loss that accompanies the EAE disease. The protective capacity of HS against the iron-mediated killing of neurons is not directly related to anti-oxidant activity, as potent anti-oxidants (ferulic acid, and partially alpha lipoic acid) could not alleviate the killing of neurons by iron, and because the F1 fraction with low HORAC or ORAC activity ameliorated iron neurotoxicity. The activity of HS is not the direct result of its anthocyanin content, as the F1 fraction had a low level, and because a commercial preparation with high anthocyanin content was not protective. HS also protected against the killing of neurons by iron when several MS disease-modifying therapies could not.

The mechanism(s) by which HS protects against the killing of cultured neurons by iron is unknown, and it is possible that HS mobilizes several defense mechanisms within cells. In support, HS protects neurons against diverse mediators of injury, including amyloidbeta, rotenone and staurosporine (Figure 4). Continuing studies in this laboratory aim to delineate how HS is neuroprotective against iron, and whether specific constituents or combinations within HS lead to its capacity to be profoundly protective against neuronal death.

Our study has several drawbacks. First, MS is a chronic disorder, while iron exposure in tissue culture is acute, so the link between the profound killing of neurons by iron in vitro to the neurodegeneration that occurs over years in MS is tenuous. Second, the mechanisms by which iron kills neurons acutely in culture are not known, so the precise targets of HS in ameliorating iron neurotoxicity in culture are uncertain. Iron can kill cells by several mechanisms, as noted earlier, including through oxidative stress, ferroptosis and misfolding of proteins, and the extent to which HS neutralizes each of these remains to be determined. Another shortcoming is that we did not evaluate how iron destroys neurons in culture and how HS could have protected against these mechanisms. As mentioned above, it is plausible that HS mobilizes several defense mechanisms within cells that confer protection, as noted by the capacity of HS to protect not only against iron but also other stressors. However, this plausibility will need to be examined in future studies. 
Supplementary Materials: The following supporting information can be downloaded at: https: / / www.mdpi.com/article/10.3390/cells11030440/s1, Supplementary Video S1: Visualization in real time of the killing of mouse neurons by iron and the protection by HS. All cells are labeled by the cell permeant Cell Tracker ${ }^{\mathrm{TM}}$ Red CMTPX dye. In control condition, few of the red cells incorporate SYTOX into their nuclei. In $50 \mu \mathrm{M}$ of $\mathrm{FeSO}_{4}$-exposed condition, the number of nuclei that turns green through SYTOX incorporation progressively increases from 8 to $20 \mathrm{~h}$. The presence of $\mathrm{HS}(100 \mu \mathrm{g} / \mathrm{mL})$ prevents neurons from being compromised, as determined by few red cells incorporating the SYTOX green dye. Supplementary Video S2: Representative disability in EAE-afflicted mice treated with HS or EAE, recorded just before sacrifice at day 24.

Author Contributions: Conceptualization, A.B., L.T. and V.W.Y.; methodology, M.K.M., J.W., R.M., R.C., H.M., P.Z., C.-C.L., A.B. and L.T.; writing—original draft preparation, V.W.Y.; writing—review and editing, all; supervision, V.W.Y.; project administration, L.T.; funding acquisition, V.W.Y. All authors have read and agreed to the published version of the manuscript.

Funding: We thank the Ralph M. Barford Foundation, Toronto, and the Canadian Institutes of Health Research for support of research funds to V.W.Y.'s laboratory. We thank the Life Sciences Fellowship program, Calgary, for support of AnthoBio activities. The Life Sciences Fellowship program is activated by Innovate Calgary and funded by Calgary Economic Development's Opportunity Calgary Investment Fund; Alberta Ministry of Jobs, Economy and Innovation; Prairies Economic Development Canada and Alberta Innovates. V.W.Y. acknowledges salary support from the Canada Research Chair program.

Institutional Review Board Statement: The use of human brain specimens for neuronal cultures is approved by the Conjoint Health Research Ethics Board at the University of Calgary (Ethics ID: REB14-1789, yearly renewal and valid through 19 January 2022). All animal experiments were conducted with ethics approval from the Animal Care Committee at the University of Calgary under guideline of the Canadian Council of Animal Care (Ethics ID: AC17-0221, yearly renewal and valid through 2 January 2022).

Informed Consent Statement: Not applicable.

Data Availability Statement: Available upon request.

Conflicts of Interest: The funders had no role in the design of the study; in the collection, analyses, or interpretation of data; in the writing of the manuscript, or in the decision to publish the results. A.B., L.T. and V.W.Y. are co-founders of AnthoBio Inc. that seeks to bring the HS extracts here into people living with MS.

\section{References}

1. Compston, A.; Coles, A. Multiple sclerosis. Lancet 2008, 372, 1502-1517. [CrossRef]

2. Klineova, S.; Lublin, F.D. Clinical Course of Multiple Sclerosis. Cold Spring Harb. Perspect. Med. 2018, 8. [CrossRef] [PubMed]

3. George, I.C.; El Mendili, M.M.; Inglese, M.; Azevedo, C.J.; Kantarci, O.; Lebrun, C.; Siva, A.; Okuda, D.T.; Pelletier, D. Cerebellar volume loss in radiologically isolated syndrome. Mult. Scler. 2019, 1352458519887346. [CrossRef]

4. Lebrun, C.; Kantarci, O.H.; Siva, A.; Pelletier, D.; Okuda, D.T.; Risconsortium. Anomalies Characteristic of Central Nervous System Demyelination: Radiologically Isolated Syndrome. Neurol. Clin. 2018, 36, 59-68. [CrossRef] [PubMed]

5. Bar-Or, A.; Li, R. Cellular immunology of relapsing multiple sclerosis: Interactions, checks, and balances. Lancet Neurol. 2021, 20, 470-483. [CrossRef]

6. Faissner, S.; Plemel, J.R.; Gold, R.; Yong, V.W. Progressive multiple sclerosis: From pathophysiology to therapeutic strategies. Nat. Rev. Drug Discov. 2019, 18, 905-922. [CrossRef]

7. Stephenson, E.; Nathoo, N.; Mahjoub, Y.; Dunn, J.F.; Yong, V.W. Iron in multiple sclerosis: Roles in neurodegeneration and repair. Nat. Rev. Neurol. 2014, 10, 459-468. [CrossRef] [PubMed]

8. Yong, H.Y.F.; Yong, V.W. Mechanism-based criteria to improve therapeutic outcomes in progressive multiple sclerosis. Nat. Rev. Neurol. 2022, 18, 40-55. [CrossRef]

9. Cronin, S.J.F.; Woolf, C.J.; Weiss, G.; Penninger, J.M. The Role of Iron Regulation in Immunometabolism and Immune-Related Disease. Front. Mol. Biosci. 2019, 6, 116. [CrossRef]

10. Urrutia, P.; Aguirre, P.; Esparza, A.; Tapia, V.; Mena, N.P.; Arredondo, M.; Gonzalez-Billault, C.; Nunez, M.T. Inflammation alters the expression of DMT1, FPN1 and hepcidin, and it causes iron accumulation in central nervous system cells. J. Neurochem. 2013, 126, 541-549. [CrossRef]

11. Stankiewicz, J.M.; Brass, S.D. Role of iron in neurotoxicity: A cause for concern in the elderly? Curr. Opin. Clin. Nutr. Metab. Care 2009, 12, 22-29. [CrossRef] [PubMed] 
12. Stockwell, B.R.; Jiang, X.; Gu, W. Emerging Mechanisms and Disease Relevance of Ferroptosis. Trends Cell Biol. 2020, 30, 478-490. [CrossRef]

13. Li, J.; Cao, F.; Yin, H.L.; Huang, Z.J.; Lin, Z.T.; Mao, N.; Sun, B.; Wang, G. Ferroptosis: Past, present and future. Cell Death Dis. 2020, 11, 88. [CrossRef] [PubMed]

14. Urrutia, P.J.; Borquez, D.A.; Nunez, M.T. Inflaming the Brain with Iron. Antioxidants 2021, 10, 61. [CrossRef] [PubMed]

15. Haider, L. Inflammation, Iron, Energy Failure, and Oxidative Stress in the Pathogenesis of Multiple Sclerosis. Oxid. Med. Cell Longev. 2015, 2015, 725370. [CrossRef] [PubMed]

16. Lee, Y.J.; Huang, X.; Kropat, J.; Henras, A.; Merchant, S.S.; Dickson, R.C.; Chanfreau, G.F. Sphingolipid signaling mediates iron toxicity. Cell Metab. 2012, 16, 90-96. [CrossRef]

17. Joppe, K.; Roser, A.E.; Maass, F.; Lingor, P. The Contribution of Iron to Protein Aggregation Disorders in the Central Nervous System. Front. Neurosci. 2019, 13, 15. [CrossRef]

18. Mochizuki, H.; Choong, C.J.; Baba, K. Parkinson's disease and iron. J. Neural Transm. 2020, 127, 181-187. [CrossRef]

19. Uranga, R.M.; Salvador, G.A. Unraveling the Burden of Iron in Neurodegeneration: Intersections with Amyloid Beta Peptide Pathology. Oxid. Med. Cell Longev. 2018, 2018, 2850341. [CrossRef]

20. Spotorno, N.; Acosta-Cabronero, J.; Stomrud, E.; Lampinen, B.; Strandberg, O.T.; van Westen, D.; Hansson, O. Relationship between cortical iron and tau aggregation in Alzheimer's disease. Brain 2020, 143, 1341-1349. [CrossRef]

21. Faissner, S.; Mishra, M.; Kaushik, D.K.; Wang, J.; Fan, Y.; Silva, C.; Rauw, G.; Metz, L.; Koch, M.; Yong, V.W. Systematic screening of generic drugs for progressive multiple sclerosis identifies clomipramine as a promising therapeutic. Nat. Commun. 2017, 8 1990. [CrossRef] [PubMed]

22. Filippi, M.; Bruck, W.; Chard, D.; Fazekas, F.; Geurts, J.J.G.; Enzinger, C.; Hametner, S.; Kuhlmann, T.; Preziosa, P.; Rovira, A.; et al Association between pathological and MRI findings in multiple sclerosis. Lancet Neurol. 2019, 18, 198-210. [CrossRef]

23. Hagemeier, J.; Ramanathan, M.; Schweser, F.; Dwyer, M.G.; Lin, F.; Bergsland, N.; Weinstock-Guttman, B.; Zivadinov, R. Ironrelated gene variants and brain iron in multiple sclerosis and healthy individuals. Neuroimage Clin. 2018, 17, 530-540. [CrossRef] [PubMed]

24. LeVine, S.M.; Bilgen, M.; Lynch, S.G. Iron accumulation in multiple sclerosis: An early pathogenic event. Expert Rev. Neurother. 2013, 13, 247-250. [CrossRef]

25. Elkady, A.M.; Cobzas, D.; Sun, H.; Blevins, G.; Wilman, A.H. Progressive iron accumulation across multiple sclerosis phenotypes revealed by sparse classification of deep gray matter. J. Magn. Reson. Imaging 2017, 46, 1464-1473. [CrossRef] [PubMed]

26. Zivadinov, R.; Tavazzi, E.; Bergsland, N.; Hagemeier, J.; Lin, F.; Dwyer, M.G.; Carl, E.; Kolb, C.; Hojnacki, D.; Ramasamy, D.; et al. Brain Iron at Quantitative MRI Is Associated with Disability in Multiple Sclerosis. Radiology 2018, 289, 487-496. [CrossRef]

27. Haider, L.; Simeonidou, C.; Steinberger, G.; Hametner, S.; Grigoriadis, N.; Deretzi, G.; Kovacs, G.G.; Kutzelnigg, A.; Lassmann, H.; Frischer, J.M. Multiple sclerosis deep grey matter: The relation between demyelination, neurodegeneration, inflammation and iron. J. Neurol. Neurosurg. Psychiatry 2014, 85, 1386-1395. [CrossRef]

28. Hametner, S.; Wimmer, I.; Haider, L.; Pfeifenbring, S.; Bruck, W.; Lassmann, H. Iron and neurodegeneration in the multiple sclerosis brain. Ann. Neurol. 2013, 74, 848-861. [CrossRef]

29. Haider, L.; Zrzavy, T.; Hametner, S.; Hoftberger, R.; Bagnato, F.; Grabner, G.; Trattnig, S.; Pfeifenbring, S.; Bruck, W.; Lassmann, H. The topograpy of demyelination and neurodegeneration in the multiple sclerosis brain. Brain 2016, 139, 807-815. [CrossRef]

30. Packer, L.; Witt, E.H.; Tritschler, H.J. alpha-Lipoic acid as a biological antioxidant. Free Radic. Biol. Med. 1995, 19, 227-250. [CrossRef]

31. Whiteman, M.; Tritschler, H.; Halliwell, B. Protection against peroxynitrite-dependent tyrosine nitration and alpha 1-antiproteinase inactivation by oxidized and reduced lipoic acid. FEBS Lett. 1996, 379, 74-76. [CrossRef]

32. Spain, R.; Powers, K.; Murchison, C.; Heriza, E.; Winges, K.; Yadav, V.; Cameron, M.; Kim, E.; Horak, F.; Simon, J.; et al. Lipoic acid in secondary progressive MS: A randomized controlled pilot trial. Neurol. Neuroimmunol. Neuroinflamm. 2017, 4, e374. [CrossRef] [PubMed]

33. Serban, C.; Sahebkar, A.; Ursoniu, S.; Andrica, F.; Banach, M. Effect of sour tea (Hibiscus sabdariffa L.) on arterial hypertension: A systematic review and meta-analysis of randomized controlled trials. J. Hypertens. 2015, 33, 1119-1127. [CrossRef] [PubMed]

34. Najafpour Boushehri, S.; Karimbeiki, R.; Ghasempour, S.; Ghalishourani, S.S.; Pourmasoumi, M.; Hadi, A.; Mbabazi, M.; Pour Z.K.; Assarroudi, M.; Mahmoodi, M.; et al. The efficacy of sour tea (Hibiscus sabdariffa L.) on selected cardiovascular disease risk factors: A systematic review and meta-analysis of randomized clinical trials. Phytother. Res. 2020, 34, 329-339. [CrossRef] [PubMed]

35. Grajeda-Iglesias, C.; Figueroa-Espinoza, M.C.; Barouh, N.; Barea, B.; Fernandes, A.; de Freitas, V.; Salas, E. Isolation and Characterization of Anthocyanins from Hibiscus sabdariffa Flowers. J. Nat. Prod. 2016, 79, 1709-1718. [CrossRef] [PubMed]

36. Maciel, L.G.; do Carmo, M.A.V.; Azevedo, L.; Daguer, H.; Molognoni, L.; de Almeida, M.M.; Granato, D.; Rosso, N.D. Hibiscus sabdariffa anthocyanins-rich extract: Chemical stability, in vitro antioxidant and antiproliferative activities. Food Chem. Toxicol. 2018, 113, 187-197. [CrossRef]

37. Zhang, R.R.; Hu, R.D.; Lu, X.Y.; Ding, X.Y.; Huang, G.Y.; Duan, L.X.; Zhang, S.J. Polyphenols from the flower of Hibiscus syriacus Linn ameliorate neuroinflammation in LPS-treated SH-SY5Y cell. Biomed. Pharmacother. 2020, 130, 110517. [CrossRef]

38. Sogo, T.; Terahara, N.; Hisanaga, A.; Kumamoto, T.; Yamashiro, T.; Wu, S.; Sakao, K.; Hou, D.X. Anti-inflammatory activity and molecular mechanism of delphinidin 3-sambubioside, a Hibiscus anthocyanin. Biofactors 2015, 41, 58-65. [CrossRef] 
39. Bakhtiari, E.; Hosseini, A.; Mousavi, S.H. Protective effect of Hibiscus sabdariffa against serum/glucose deprivation-induced PC12 cells injury. Avicenna J. Phytomed. 2015, 5, 231-237.

40. Chiaino, E.; Micucci, M.; Cosconati, S.; Novellino, E.; Budriesi, R.; Chiarini, A.; Frosini, M. Olive Leaves and Hibiscus Flowers Extracts-Based Preparation Protect Brain from Oxidative Stress-Induced Injury. Antioxidants 2020, 9, 806. [CrossRef]

41. Hritcu, L.; Foyet, H.S.; Stefan, M.; Mihasan, M.; Asongalem, A.E.; Kamtchouing, P. Neuroprotective effect of the methanolic extract of Hibiscus asper leaves in 6-hydroxydopamine-lesioned rat model of Parkinson's disease. J. Ethnopharmacol. 2011, 137, 585-591. [CrossRef] [PubMed]

42. Foyet, H.S.; Hritcu, L.; Ciobica, A.; Stefan, M.; Kamtchouing, P.; Cojocaru, D. Methanolic extract of Hibiscus asper leaves improves spatial memory deficits in the 6-hydroxydopamine-lesion rodent model of Parkinson's disease. J. Ethnopharmacol. 2011, 133, 773-779. [CrossRef] [PubMed]

43. El-Shiekh, R.A.; Ashour, R.M.; Abd El-Haleim, E.A.; Ahmed, K.A.; Abdel-Sattar, E. Hibiscus sabdariffa L.: A potent natural neuroprotective agent for the prevention of streptozotocin-induced Alzheimer's disease in mice. Biomed. Pharmacother. 2020, 128, 110303. [CrossRef] [PubMed]

44. Hou, D.X.; Tong, X.; Terahara, N.; Luo, D.; Fujii, M. Delphinidin 3-sambubioside, a Hibiscus anthocyanin, induces apoptosis in human leukemia cells through reactive oxygen species-mediated mitochondrial pathway. Arch. Biochem. Biophys. 2005, 440, 101-109. [CrossRef]

45. Lee, J.; Durst, R.W.; Wrolstad, R.E. Determination of total monomeric anthocyanin pigment content of fruit juices, beverages, natural colorants, and wines by the $\mathrm{pH}$ differential method: Collaborative study. J. AOAC Int. 2005, 88, 1269-1278. [CrossRef] [PubMed]

46. Vecil, G.G.; Larsen, P.H.; Corley, S.M.; Herx, L.M.; Besson, A.; Goodyer, C.G.; Yong, V.W. Interleukin-1 is a key regulator of matrix metalloproteinase-9 expression in human neurons in culture and following mouse brain trauma in vivo. J. Neurosci. Res. 2000, 61, 212-224. [CrossRef]

47. Faissner, S.; Mahjoub, Y.; Mishra, M.; Haupeltshofer, S.; Hahn, J.N.; Gold, R.; Koch, M.; Metz, L.M.; Ben-Hur, T.; Yong, V.W. Unexpected additive effects of minocycline and hydroxychloroquine in models of multiple sclerosis: Prospective combination treatment for progressive disease? Mult. Scler. 2018, 24, 1543-1556. [CrossRef]

48. Cua, R.C.; Lau, L.W.; Keough, M.B.; Midha, R.; Apte, S.S.; Yong, V.W. Overcoming neurite-inhibitory chondroitin sulfate proteoglycans in the astrocyte matrix. Glia 2013, 61, 972-984. [CrossRef]

49. Dong, Y.; D’Mello, C.; Pinsky, W.; Lozinski, B.M.; Kaushik, D.K.; Ghorbani, S.; Moezzi, D.; Brown, D.; Melo, F.C.; Zandee, S.; et al. Oxidized phosphatidylcholines found in multiple sclerosis lesions mediate neurodegeneration and are neutralized by microglia. Nat. Neurosci. 2021, 24, 489-503. [CrossRef]

50. Mishra, M.K.; Wang, J.; Keough, M.B.; Fan, Y.; Silva, C.; Sloka, S.; Hayardeny, L.; Bruck, W.; Yong, V.W. Laquinimod reduces neuroaxonal injury through inhibiting microglial activation. Ann. Clin. Transl. Neurol. 2014, 1, 409-422. [CrossRef]

51. Sloka, S.; Zhornitsky, S.; Silva, C.; Metz, L.M.; Yong, V.W. 1,25-Dihydroxyvitamin D3 Protects against Immune-Mediated Killing of Neurons in Culture and in Experimental Autoimmune Encephalomyelitis. PLoS ONE 2015, 10, e0144084. [CrossRef] [PubMed]

52. Brown, D.; Moezzi, D.; Dong, Y.; Koch, M.; Yong, V.W. Combination of Hydroxychloroquine and Indapamide Attenuates Neurodegeneration in Models Relevant to Multiple Sclerosis. Neurotherapeutics 2021, 18, 387-400. [CrossRef] [PubMed]

53. Grenier, D.; Huot, M.P.; Mayrand, D. Iron-chelating activity of tetracyclines and its impact on the susceptibility of Actinobacillus actinomycetemcomitans to these antibiotics. Antimicrob. Agents Chemother. 2000, 44, 763-766. [CrossRef]

54. Jhamandas, J.H.; Mactavish, D. beta-Amyloid protein (Abeta) and human amylin regulation of apoptotic genes occurs through the amylin receptor. Apoptosis 2012, 17, 37-47. [CrossRef] [PubMed]

55. Rekha, K.R.; Inmozhi Sivakamasundari, R. Geraniol Protects Against the Protein and Oxidative Stress Induced by Rotenone in an In Vitro Model of Parkinson's Disease. Neurochem. Res. 2018, 43, 1947-1962. [CrossRef]

56. Wiesner, D.A.; Dawson, G. Staurosporine induces programmed cell death in embryonic neurons and activation of the ceramide pathway. J. Neurochem. 1996, 66, 1418-1425. [CrossRef] [PubMed]

57. Wuerch, E.; Mishra, M.; Melo, H.; Ebacher, V.; Yong, V.W. Quantitative analysis of spinal cord neuropathology in experimental autoimmune encephalomyelitis. J. Neuroimmunol. 2022, 362, 577777. [CrossRef]

58. Rommer, P.S.; Milo, R.; Han, M.H.; Satyanarayan, S.; Sellner, J.; Hauer, L.; Illes, Z.; Warnke, C.; Laurent, S.; Weber, M.S.; et al Immunological Aspects of Approved MS Therapeutics. Front. Immunol. 2019, 10, 1564. [CrossRef]

59. Linker, R.A.; Lee, D.H.; Ryan, S.; van Dam, A.M.; Conrad, R.; Bista, P.; Zeng, W.; Hronowsky, X.; Buko, A.; Chollate, S.; et al. Fumaric acid esters exert neuroprotective effects in neuroinflammation via activation of the Nrf2 antioxidant pathway. Brain 2011, 134, 678-692. [CrossRef]

60. Campolo, M.; Casili, G.; Lanza, M.; Filippone, A.; Paterniti, I.; Cuzzocrea, S.; Esposito, E. Multiple mechanisms of dimethyl fumarate in amyloid beta-induced neurotoxicity in human neuronal cells. J. Cell Mol. Med. 2018, 22, 1081-1094. [CrossRef]

61. Di Menna, L.; Molinaro, G.; Di Nuzzo, L.; Riozzi, B.; Zappulla, C.; Pozzilli, C.; Turrini, R.; Caraci, F.; Copani, A.; Battaglia, G.; et al. Fingolimod protects cultured cortical neurons against excitotoxic death. Pharmacol. Res. 2013, 67, 1-9. [CrossRef] [PubMed]

62. Colombo, E.; Di Dario, M.; Capitolo, E.; Chaabane, L.; Newcombe, J.; Martino, G.; Farina, C. Fingolimod may support neuroprotection via blockade of astrocyte nitric oxide. Ann. Neurol. 2014, 76, 325-337. [CrossRef] [PubMed]

63. Comi, G.; Jeffery, D.; Kappos, L.; Montalban, X.; Boyko, A.; Rocca, M.A.; Filippi, M.; Group, A.S. Placebo-controlled trial of oral laquinimod for multiple sclerosis. N. Engl. J. Med. 2012, 366, 1000-1009. [CrossRef] [PubMed] 
64. Filippi, M.; Rocca, M.A.; Pagani, E.; De Stefano, N.; Jeffery, D.; Kappos, L.; Montalban, X.; Boyko, A.N.; Comi, G.; Group, A.S. Placebo-controlled trial of oral laquinimod in multiple sclerosis: MRI evidence of an effect on brain tissue damage. J. Neurol. Neurosurg. Psychiatry 2014, 85, 851-858. [CrossRef] [PubMed]

65. Gentile, A.; Musella, A.; De Vito, F.; Fresegna, D.; Bullitta, S.; Rizzo, F.R.; Centonze, D.; Mandolesi, G. Laquinimod ameliorates excitotoxic damage by regulating glutamate re-uptake. J. Neuroinflammation 2018, 15, 5. [CrossRef] [PubMed]

66. Colombo, E.; Bassani, C.; De Angelis, A.; Ruffini, F.; Ottoboni, L.; Comi, G.; Martino, G.; Farina, C. Siponimod (BAF312) Activates Nrf2 While Hampering NFkappaB in Human Astrocytes, and Protects From Astrocyte-Induced Neurodegeneration. Front. Immunol. 2020, 11, 635. [CrossRef]

67. Gentile, A.; Musella, A.; Bullitta, S.; Fresegna, D.; De Vito, F.; Fantozzi, R.; Piras, E.; Gargano, F.; Borsellino, G.; Battistini, L.; et al. Siponimod (BAF312) prevents synaptic neurodegeneration in experimental multiple sclerosis. J. Neuroinflammation 2016, 13, 207. [CrossRef]

68. Salehi, B.; Sharifi-Rad, J.; Cappellini, F.; Reiner, Z.; Zorzan, D.; Imran, M.; Sener, B.; Kilic, M.; El-Shazly, M.; Fahmy, N.M.; et al. The Therapeutic Potential of Anthocyanins: Current Approaches Based on Their Molecular Mechanism of Action. Front. Pharmacol. 2020, 11, 1300. [CrossRef]

69. Zdunska, K.; Dana, A.; Kolodziejczak, A.; Rotsztejn, H. Antioxidant Properties of Ferulic Acid and Its Possible Application. Skin Pharmacol. Physiol. 2018, 31, 332-336. [CrossRef]

70. Packer, L.; Tritschler, H.J.; Wessel, K. Neuroprotection by the metabolic antioxidant alpha-lipoic acid. Free Radic. Biol. Med. 1997, 22, 359-378. [CrossRef]

71. Scott, B.C.; Aruoma, O.I.; Evans, P.J.; O’Neill, C.; Van der Vliet, A.; Cross, C.E.; Tritschler, H.; Halliwell, B. Lipoic and dihydrolipoic acids as antioxidants. A critical evaluation. Free Radic. Res. 1994, 20, 119-133. [CrossRef] [PubMed]

72. Yadav, V.; Marracci, G.; Lovera, J.; Woodward, W.; Bogardus, K.; Marquardt, W.; Shinto, L.; Morris, C.; Bourdette, D. Lipoic acid in multiple sclerosis: A pilot study. Mult. Scler. 2005, 11, 159-165. [CrossRef] [PubMed]

73. Doi, Y.; Takeuchi, H.; Horiuchi, H.; Hanyu, T.; Kawanokuchi, J.; Jin, S.; Parajuli, B.; Sonobe, Y.; Mizuno, T.; Suzumura, A Fingolimod phosphate attenuates oligomeric amyloid beta-induced neurotoxicity via increased brain-derived neurotrophic factor expression in neurons. PLoS ONE 2013, 8, e61988. [CrossRef] [PubMed]

74. Kunkl, M.; Frascolla, S.; Amormino, C.; Volpe, E.; Tuosto, L. T Helper Cells: The Modulators of Inflammation in Multiple Sclerosis. Cells 2020, 9, 482. [CrossRef]

75. Kaskow, B.J.; Baecher-Allan, C. Effector T Cells in Multiple Sclerosis. Cold Spring Harb. Perspect. Med. 2018, 8. [CrossRef]

76. De Stefano, N.; Matthews, P.M.; Fu, L.; Narayanan, S.; Stanley, J.; Francis, G.S.; Antel, J.P.; Arnold, D.L. Axonal damage correlates with disability in patients with relapsing-remitting multiple sclerosis. Results of a longitudinal magnetic resonance spectroscopy study. Brain 1998, 121, 1469-1477. [CrossRef]

77. Eshaghi, A.; Prados, F.; Brownlee, W.J.; Altmann, D.R.; Tur, C.; Cardoso, M.J.; De Angelis, F.; van de Pavert, S.H.; Cawley, N.; De Stefano, N.; et al. Deep gray matter volume loss drives disability worsening in multiple sclerosis. Ann. Neurol. 2018, 83, 210-222. [CrossRef]

78. Zivadinov, R.; Sepcic, J.; Nasuelli, D.; De Masi, R.; Bragadin, L.M.; Tommasi, M.A.; Zambito-Marsala, S.; Moretti, R.; Bratina, A.; Ukmar, M.; et al. A longitudinal study of brain atrophy and cognitive disturbances in the early phase of relapsing-remitting multiple sclerosis. J. Neurol. Neurosurg. Psychiatry 2001, 70, 773-780. [CrossRef]

79. Alcaide-Leon, P.; Cybulsky, K.; Sankar, S.; Casserly, C.; Leung, G.; Hohol, M.; Selchen, D.; Montalban, X.; Bharatha, A.; Oh, J. Quantitative spinal cord MRI in radiologically isolated syndrome. Neurol. Neuroimmunol. Neuroinflamm. 2018, 5, e436. [CrossRef]

80. Azevedo, C.J.; Overton, E.; Khadka, S.; Buckley, J.; Liu, S.; Sampat, M.; Kantarci, O.; Lebrun Frenay, C.; Siva, A.; Okuda, D.T.; et al. Early CNS neurodegeneration in radiologically isolated syndrome. Neurol. Neuroimmunol. Neuroinflamm. 2015, 2, e102. [CrossRef]

81. Eshaghi, A.; Marinescu, R.V.; Young, A.L.; Firth, N.C.; Prados, F.; Jorge Cardoso, M.; Tur, C.; De Angelis, F.; Cawley, N.; Brownlee, W.J.; et al. Progression of regional grey matter atrophy in multiple sclerosis. Brain 2018, 141, 1665-1677. [CrossRef] [PubMed]

82. Stromillo, M.L.; Giorgio, A.; Rossi, F.; Battaglini, M.; Hakiki, B.; Malentacchi, G.; Santangelo, M.; Gasperini, C.; Bartolozzi, M.L.; Portaccio, E.; et al. Brain metabolic changes suggestive of axonal damage in radiologically isolated syndrome. Neurology 2013, 80, 2090-2094. [CrossRef] [PubMed]

83. Bjornevik, K.; Munger, K.L.; Cortese, M.; Barro, C.; Healy, B.C.; Niebuhr, D.W.; Scher, A.I.; Kuhle, J.; Ascherio, A. Serum Neurofilament Light Chain Levels in Patients With Presymptomatic Multiple Sclerosis. JAMA Neurol. 2020, 77, 58-64. [CrossRef] [PubMed]

84. Matute-Blanch, C.; Villar, L.M.; Alvarez-Cermeno, J.C.; Rejdak, K.; Evdoshenko, E.; Makshakov, G.; Nazarov, V.; Lapin, S.; Midaglia, L.; Vidal-Jordana, A.; et al. Neurofilament light chain and oligoclonal bands are prognostic biomarkers in radiologically isolated syndrome. Brain 2018, 141, 1085-1093. [CrossRef] [PubMed]

85. Calabrese, M.; Magliozzi, R.; Ciccarelli, O.; Geurts, J.J.; Reynolds, R.; Martin, R. Exploring the origins of grey matter damage in multiple sclerosis. Nat. Rev. Neurosci. 2015, 16, 147-158. [CrossRef]

86. Mendiola, A.S.; Ryu, J.K.; Bardehle, S.; Meyer-Franke, A.; Ang, K.K.; Wilson, C.; Baeten, K.M.; Hanspers, K.; Merlini, M.; Thomas, S.; et al. Transcriptional profiling and therapeutic targeting of oxidative stress in neuroinflammation. Nat. Immunol. 2020, 21, 513-524. [CrossRef]

87. Campbell, G.R.; Ziabreva, I.; Reeve, A.K.; Krishnan, K.J.; Reynolds, R.; Howell, O.; Lassmann, H.; Turnbull, D.M.; Mahad, D.J. Mitochondrial DNA deletions and neurodegeneration in multiple sclerosis. Ann. Neurol. 2011, 69, 481-492. [CrossRef] 
88. Macrez, R.; Stys, P.K.; Vivien, D.; Lipton, S.A.; Docagne, F. Mechanisms of glutamate toxicity in multiple sclerosis: Biomarker and therapeutic opportunities. Lancet Neurol. 2016, 15, 1089-1102. [CrossRef]

89. Woo, M.S.; Ufer, F.; Rothammer, N.; Di Liberto, G.; Binkle, L.; Haferkamp, U.; Sonner, J.K.; Engler, J.B.; Hornig, S.; Bauer, S.; et al. Neuronal metabotropic glutamate receptor 8 protects against neurodegeneration in CNS inflammation. J. Exp. Med. 2021, 218. [CrossRef]

90. Lassmann, H.; van Horssen, J. Oxidative stress and its impact on neurons and glia in multiple sclerosis lesions. Biochim. Biophys. Acta 2016, 1862, 506-510. [CrossRef]

91. Adamczyk, B.; Adamczyk-Sowa, M. New Insights into the Role of Oxidative Stress Mechanisms in the Pathophysiology and Treatment of Multiple Sclerosis. Oxid. Med. Cell Longev. 2016, 2016, 1973834. [CrossRef] [PubMed]

92. van Horssen, J.; Schreibelt, G.; Drexhage, J.; Hazes, T.; Dijkstra, C.D.; van der Valk, P.; de Vries, H.E. Severe oxidative damage in multiple sclerosis lesions coincides with enhanced antioxidant enzyme expression. Free Radic. Biol. Med. 2008, 45, 1729-1737. [CrossRef] [PubMed]

93. Nikic, I.; Merkler, D.; Sorbara, C.; Brinkoetter, M.; Kreutzfeldt, M.; Bareyre, F.M.; Bruck, W.; Bishop, D.; Misgeld, T.; Kerschensteiner, M. A reversible form of axon damage in experimental autoimmune encephalomyelitis and multiple sclerosis. Nat. Med. 2011, 17, 495-499. [CrossRef] [PubMed]

94. Kemp, K.; Redondo, J.; Hares, K.; Rice, C.; Scolding, N.; Wilkins, A. Oxidative injury in multiple sclerosis cerebellar grey matter Brain Res. 2016, 1642, 452-460. [CrossRef] [PubMed]

95. Choi, I.Y.; Lee, P.; Hughes, A.J.; Denney, D.R.; Lynch, S.G. Longitudinal changes of cerebral glutathione (GSH) levels associated with the clinical course of disease progression in patients with secondary progressive multiple sclerosis. Mult. Scler. 2017, 23, 956-962. [CrossRef] [PubMed]

96. Choi, I.Y.; Lee, P.; Adany, P.; Hughes, A.J.; Belliston, S.; Denney, D.R.; Lynch, S.G. In vivo evidence of oxidative stress in brains of patients with progressive multiple sclerosis. Mult. Scler. 2018, 24, 1029-1038. [CrossRef]

97. Scuderi, S.A.; Ardizzone, A.; Paterniti, I.; Esposito, E.; Campolo, M. Antioxidant and Anti-inflammatory Effect of Nrf2 Inducer Dimethyl Fumarate in Neurodegenerative Diseases. Antioxidants 2020, 9, 630. [CrossRef]

98. Lee, N.J.; Ha, S.K.; Sati, P.; Absinta, M.; Nair, G.; Luciano, N.J.; Leibovitch, E.C.; Yen, C.C.; Rouault, T.A.; Silva, A.C.; et al. Potential role of iron in repair of inflammatory demyelinating lesions. J. Clin. Investig. 2019, 129, 4365-4376. [CrossRef]

99. Cheli, V.T.; Correale, J.; Paez, P.M.; Pasquini, J.M. Iron Metabolism in Oligodendrocytes and Astrocytes, Implications for Myelination and Remyelination. ASN Neuro 2020, 12, 1759091420962681. [CrossRef]

100. Hulet, S.W.; Powers, S.; Connor, J.R. Distribution of transferrin and ferritin binding in normal and multiple sclerotic human brains. J. Neurol. Sci. 1999, 165, 48-55. [CrossRef]

101. Bagnato, F.; Hametner, S.; Yao, B.; van Gelderen, P.; Merkle, H.; Cantor, F.K.; Lassmann, H.; Duyn, J.H. Tracking iron in multiple sclerosis: A combined imaging and histopathological study at 7 Tesla. Brain 2011, 134, 3602-3615. [CrossRef] [PubMed]

102. Hu, C.L.; Nydes, M.; Shanley, K.L.; Morales Pantoja, I.E.; Howard, T.A.; Bizzozero, O.A. Reduced expression of the ferroptosis inhibitor glutathione peroxidase-4 in multiple sclerosis and experimental autoimmune encephalomyelitis. J. Neurochem. 2019, 148, 426-439. [CrossRef] [PubMed] 